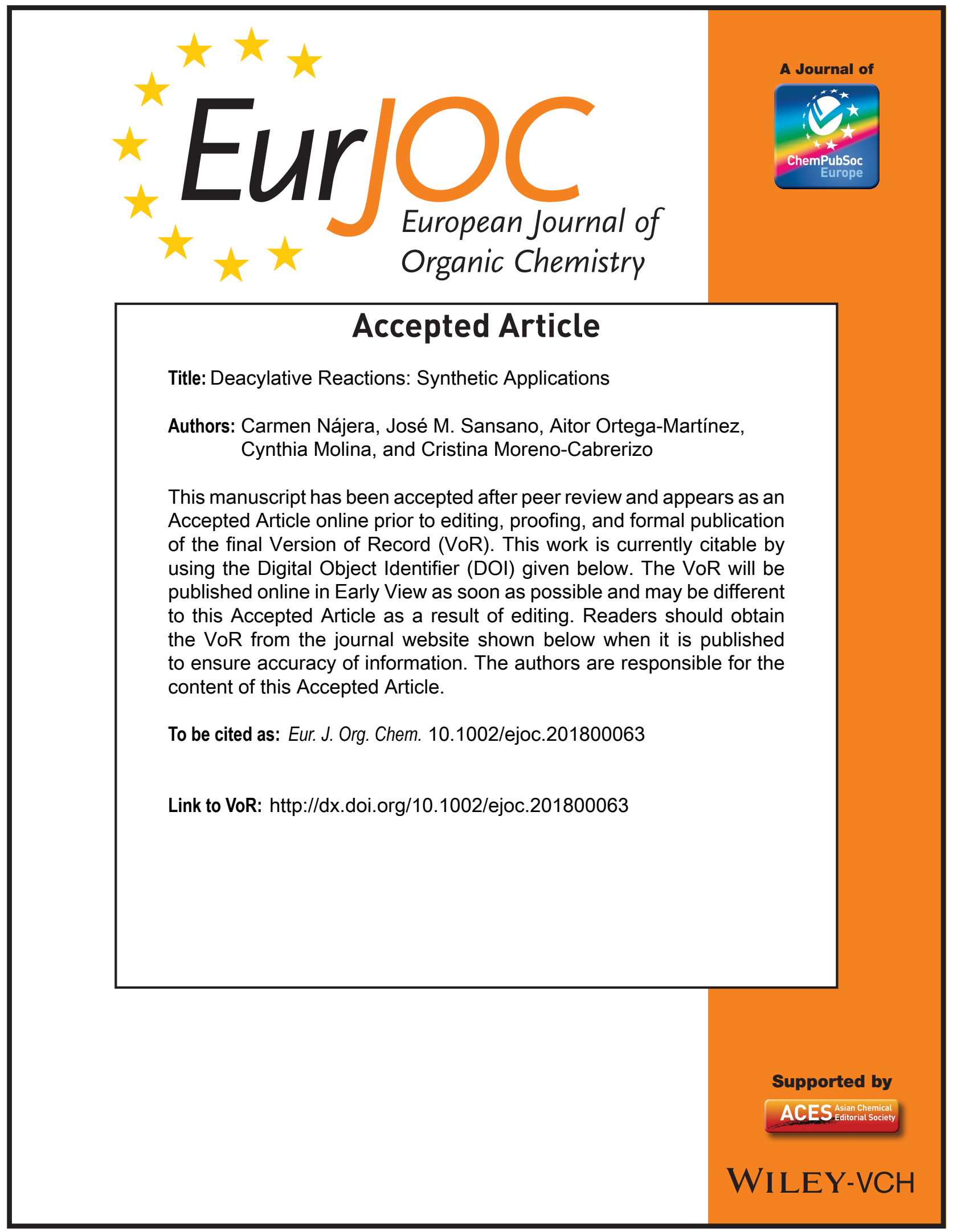




\title{
Deacylative Reactions: Synthetic Applications
}

\section{Aitor Ortega-Martínez, ${ }^{[a, b]}$ Cynthia Molina, ${ }^{[a, b]}$ Cristina Moreno-Cabrerizo, ${ }^{[a, b]}$ José M. Sansano, ${ }^{*[a, b]}$ and Carmen Nájera*[a]}

[a] Departamento de Química Orgánica and Centro de Innovación en Química Avanzada (ORFEO-CINQA), Facultad de Ciencias, Universidad de Alicante 03080-Alicante, Spain.

[b] Instituto de Síntesis Orgánica, Facultad de Ciencias, Universidad de Alicante 03080-Alicante, Spain.

E-mail: jmsansano@ua.es; https://cvnet.cpd.ua.es/curriculum-breve/es/sansano-gil-jose-miguel/10547

E-mail: cnajera@ua.es; https://cvnet.cpd.ua.es/curriculum-breve/es/najera-domingo-carmen/29835

Keywords: Enolates / Alkylation / Palladium catalysis / Allylic alcohols / Fluorine /

\begin{abstract}
Herein we introduce the recent developments of a new strategy based on deacylative alkylation (DaA) reactions for the generation of quaternary stereocenters based on the in situ preparation and functionalization of enolates under very mild reaction conditions. Palladiumcatalyzed deacylative allylation and benzylation reactions of carbon nucleophiles are performed with the corresponding alcohols. This methodology has been applied to the synthesis of the calcium ion chanel blocker verapamil, the antiviral (+)-hamigeran B, several oxindole precursors of esermethole, horsfiline, physostigmine, phenserine, meso-folicanthine, meso-chinonanthine and the dimer cyclotriptamine alkaloids. Base-promoted deacylative reactions allow the functionalization of 2-oxindole enolates at the 3-position with alkyl halides and electrophilic alkenes. In the presence of oxygen or air, 3-hydroxy-2-oxindoles are prepared by deacylative oxidation. Detrifluoroacylative reactions are promoted by a base generating fluoroenolates, which can participate in aldol, Mannich and Michael reactions for the preparation of important fluorinated intermediates. Finally, palladium-catalyzed deacylative cross-coupling of acetyldiazoacetates and phosphonates with aryl iodides let to the formation of aryldiazoacetates and phosphonates, respectively. The same process, with 2-iodoazoarenes and 2-iodoaryltriazenes, gives $2 \mathrm{H}$-indazoles, which are important pharmacophores.
\end{abstract}

\section{Introduction}

Classical alkylation of enolates requires, for the deprotonation step, the use of strong bases and low temperatures under strict anhydrous conditions (Scheme 1, eq. 1). Alternatively, acetyl acetic and malonic ester syntheses can be performed under mild reaction conditions and, after alkylation and retro-Claisen condensation, the corresponding alkylated carbonyl compound can be prepared by means of a two-step procedure (Scheme 1, eq. 2). Likewise, the acyl group can be used as "traceless" directing group in retro-Claisen condensation ${ }^{[1]}$ for the generation of enolates and other carbon nucleophiles, which also can be also trapped by different electrophiles (Scheme 1, eq. 3). This deacylative alkylation (DaA) can also take place under base-promoted conditions and the resulting enolate reacts with an electrophile already present in the reaction media in one step procedure. 


\section{Alkylation of Enolates}

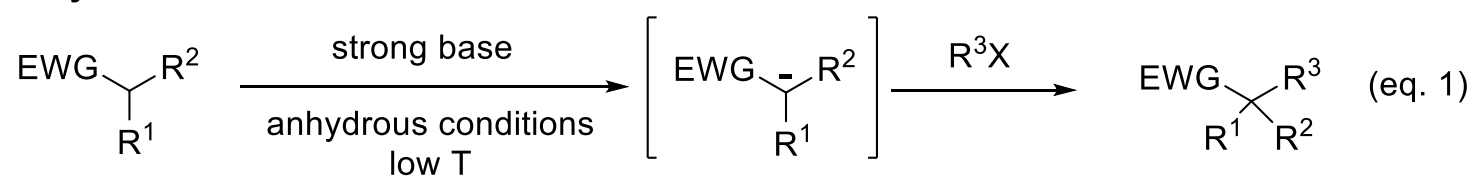

\section{Acetyl Acetic and Malonic Ester Syntheses}

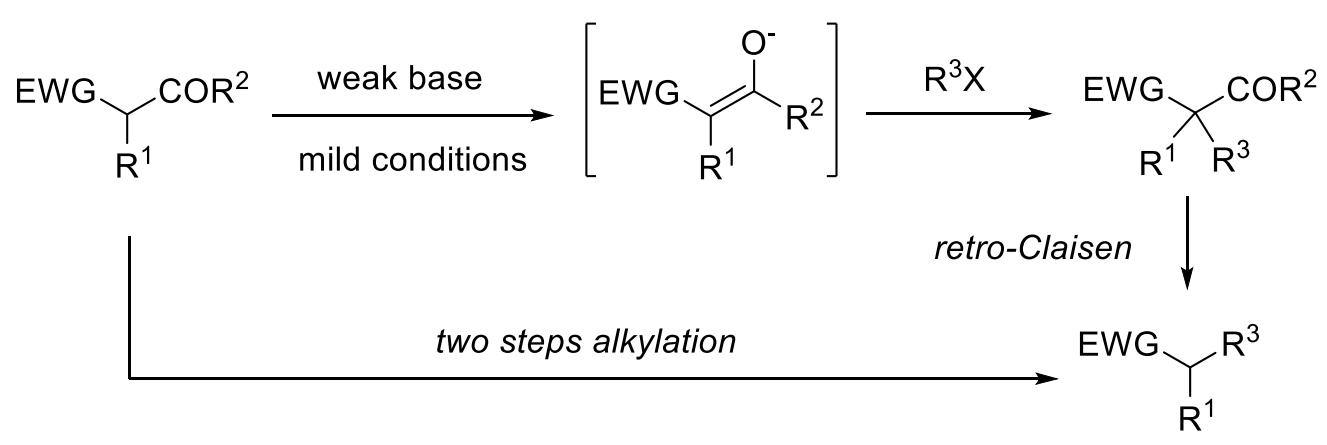

\section{Deacylative Alkylations (DaA)}

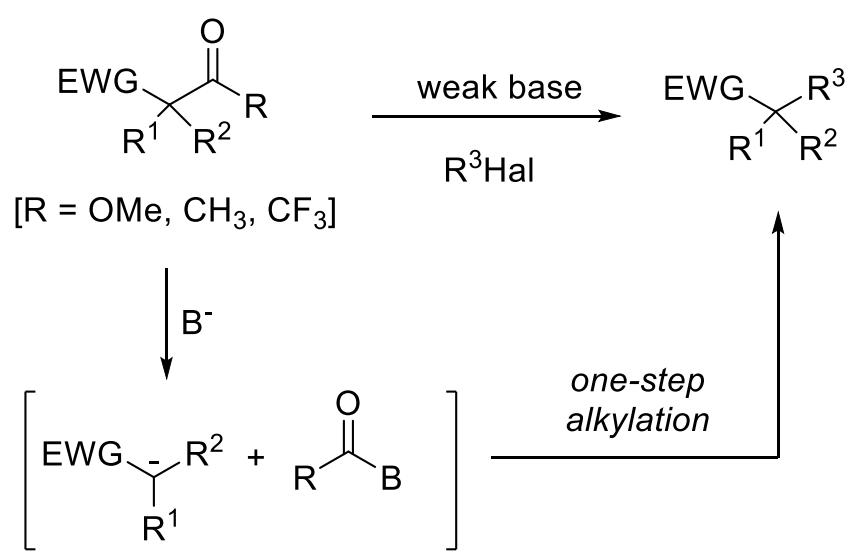

(eq. 3)

Scheme 1. Alkylation of enolates.

Under Pd-catalysis, the generation of enolates can be performed by a decarboxylation process through a C-C bond cleavage starting from $\beta$-keto esters or vinyl carbonates. This well-known decarboxylative allylation (DcA) can be performed also under mild reaction conditions (Scheme 2). ${ }^{[2]}$ In the first case, allyl esters have to be prepared as starting compounds in order to generate the $\pi$-allylpalladium intermediate, which will be attacked by the enolate, generated after decarboxylation (Scheme 2, eq. 1). On the other hand, in the case of allyl enol carbonates, palladium(0) will insert into the $\mathrm{C}-\mathrm{O}$ bond giving the $\pi$-allyl palladium intermediate and, after decarboxylation, the enolate will react with this intermediate giving the allylated product (Scheme 2, eq. 2). These biomometic decarboxylative reactions (DcA) have been used in aldol, Michael additions and allylic alkylations under neutral conditions and have been applied to the synthesis of natural products. ${ }^{[3]}$

The deacylative allylation (DaA), which is also based on a $\mathrm{C}-\mathrm{C}$ bond cleavage, can be carried out under palladiumcatalysis as well (Scheme 2, eq. 3), and has several advantages versus the decarboxylative allylation. Thus, the synthesis of the acyl derivative can be achieved using simple reaction conditions through a Claisen condensation. However, the DcA requires the preparation either of the allyl (or benzyl) ester by transesterification or of the allyl (or benzyl) enol ether by means of the corresponding chloroformates. In the DaA, the allyl or benzyl group can be introduced using allylic (or benzylic) alcohols and therefore the alkylation takes place directly from the corresponding alcohols. Thus, the retro-Claisen condensation is able to activate both the nucleophile and electrophile towards Pd-catalyzed allylation (or benzoylation). 


\section{Decarboxylative Allylations (DcA)}<smiles>[R]COC(=O)OC1=CCCC1</smiles>

\section{Deacylative Allylations (DaA)}

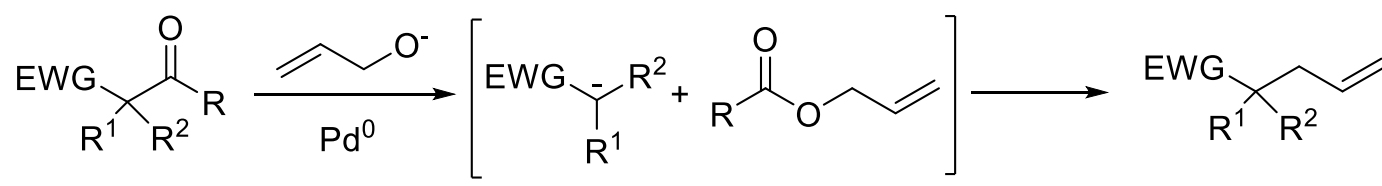

$\left[\mathrm{R}=\mathrm{OMe}, \mathrm{CH}_{3}\right]$

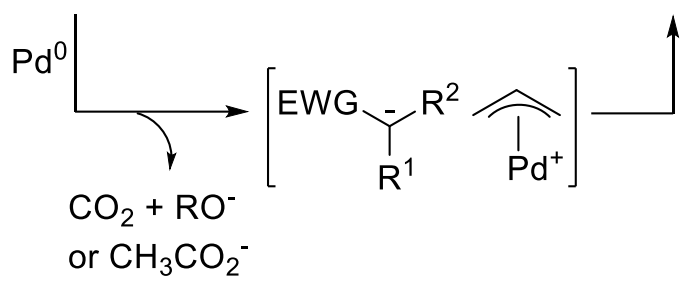

Scheme 2. Pd-Catalyzed decarboxylative and deacylative allylation reactions.

The focus of this report is to review the synthetic applications of these recently emerged DaA reactions by regioselective nucleophilic substitution of the in situ generated enolates and carbon nucleophiles allowing the generation of quaternary stereocenters at the $\alpha$-position of ketones and other carbonyl derivatives or activated carbon nucleophiles.

\section{Deacylative Alkylation}

Palladium-catalyzed deacylative allylations of carbon nucleophiles with allylic alcohols was firstly described by Grenning and Tunge. ${ }^{[4]}$ In this type of DaA, the allylic alkoxide induces the retro-Claisen condensation generating an allylic acetate or carbonate and the carbon nucleophile, which can be coupled with the in situ generated $\pi$-allylpalladium intermediate (Scheme 3).

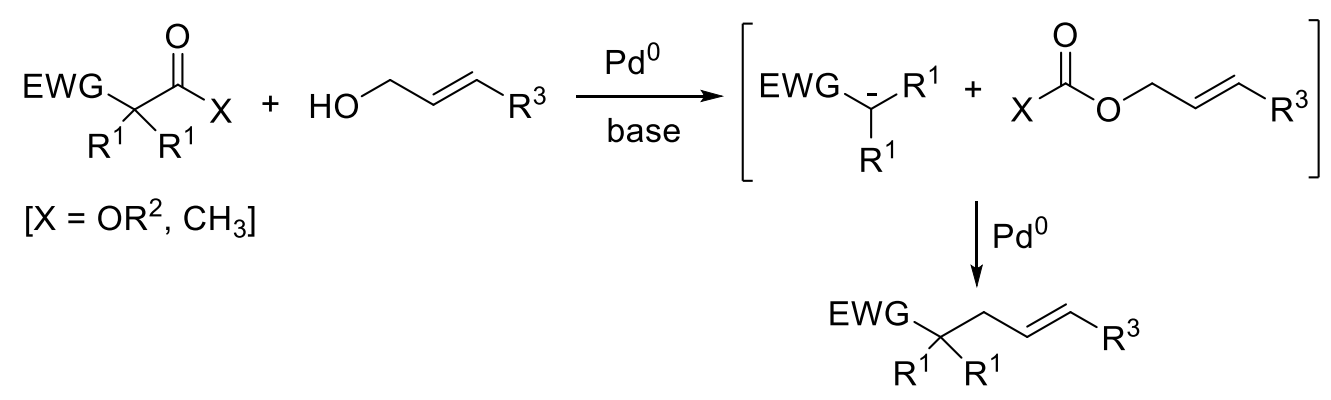

Scheme 3. Pd-catalyzed deacylative allylation of carbon nucleophiles with allylic alcohols.

$\alpha$-Allylated $\alpha$-nitroketones were allylated to give diallylated nitroalkanes using $2.5 \mathrm{~mol}-\%$ of $\mathrm{Pd}\left(\mathrm{PPh}_{3}\right)_{4}$ and 1 equiv. of $\mathrm{Cs}_{2} \mathrm{CO}_{3}$ as base, at $80^{\circ} \mathrm{C}$, in high yields (Scheme 4, eq. 1). In general, the linear allylation products were mainly formed with primary allylic alcohols and, in the case of crotyl alcohol, the E-diastereomer was isolated as the major compound. Secondary allylic alcohols such as hexen-3-ol furnished also the linear product but in only $25 \%$ yield. This diallylation can be performed in a tandem process under the same reaction conditions employing different allylic derivatives such as a carbonate and an alcohol. Starting from $\alpha$-phenyl or $\alpha$-alkyl $\alpha$-nitroketones, in the presence of the allylic carbonate and 
alcohol, a tandem Tsuji-Trost allylation of the stabilized nitronates with the carbonate, followed by DaA with the alcohol, afforded unsymmetrical 1,6-dienes (Scheme 4, eq. 2). ${ }^{[4]}$

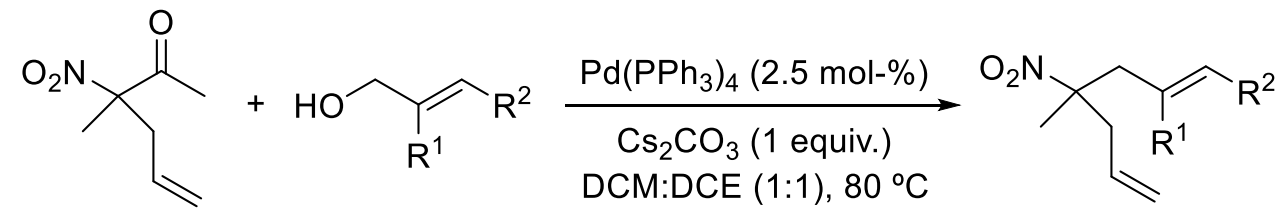

$79-92 \%$<smiles>[R]C=CCOCC=C[R]</smiles><smiles>[R]C=CCC([R])(CC=C[R])[N+](=O)[O-]</smiles>

$47-93 \%$

Scheme 4. Pd-catalyzed deacylative allylation of $\alpha$-nitroketones.

The in situ generationof acyclic and cyclic ketone enolates was described by the same group. They started from the corresponding 1,3-dicarbonyl compounds. ${ }^{[4,5]}$ In this case, the Pd-catalyzed allylation with allylic alcohols was performed using $\mathrm{NaH}$ as base in THF at $60^{\circ} \mathrm{C}$; also DMSO or MeCN, and in some cases NMP, were used as solvents together with $\mathrm{Cs}_{2} \mathrm{CO}_{3}$ (Scheme 5). Here, aryl substituted acyclic ketones gave the best results, and several cyclic ketones such as indanones and $\alpha$ - or $\beta$-tetralones were regioselectively allylated. In the example involving an unsymmetrical acyclic 1,3-diketone a mixture of regioisomers was obtained.

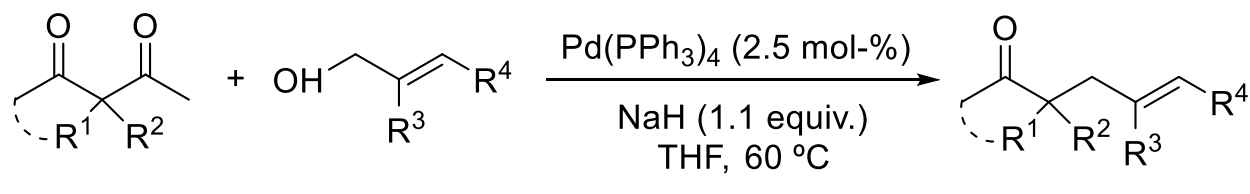

$60-93 \%$

\section{1,3-Dicarbonyl compounds}<smiles>[R]C([Al])(C(C)=O)C(C)=O</smiles><smiles>[R]C([Al])(C(C)=O)C(=O)CC</smiles><smiles>[R]C([Y])(C(C)=O)C(=O)c1ccccc1C</smiles><smiles>[R]C1(C(C)=O)C(=O)CCc2ccccc21</smiles>

$$
(\mathrm{n}=1,2)
$$

Scheme 5. Pd-catalyzed deacylativeallylation of 1,3-dicarbonyl compounds.

The DaA of $\alpha$-arylcyanoacetones was performed with allylic alcohols, $\mathrm{NaH}$ as base and DMSO as solvent. Room temperature was needed when allyl alcohol was tested, whilst substituted primary allylic alcohols have to react at $60{ }^{\circ} \mathrm{C}$ to give the corresponding $\alpha$-quaternary allylated nitriles in good yields (Scheme 6 ) ${ }^{[5]}$ This methodology has been applied to the synthesis of a precursor of verapamil, a calcium ion channel-blocker used for the treatment of cardiovascular disorders (Scheme 6). The required $\alpha$-arylcyanoacetone was prepared in two steps from homoveratronitrile by acetylation and alkylation with isopropyl iodide in $66 \%$ overall yield. Further DaA with allyl alcohol provided the desired product in $81 \%$ yield. 


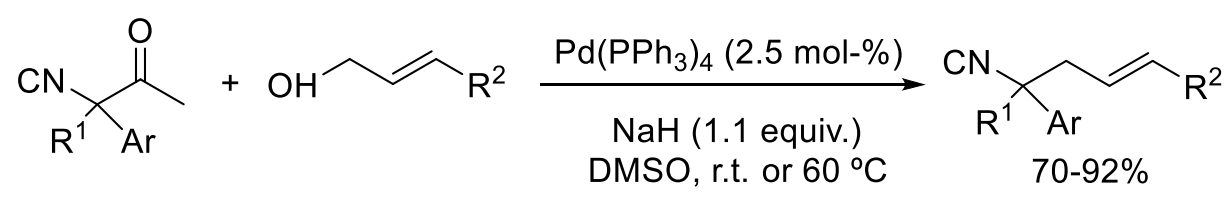

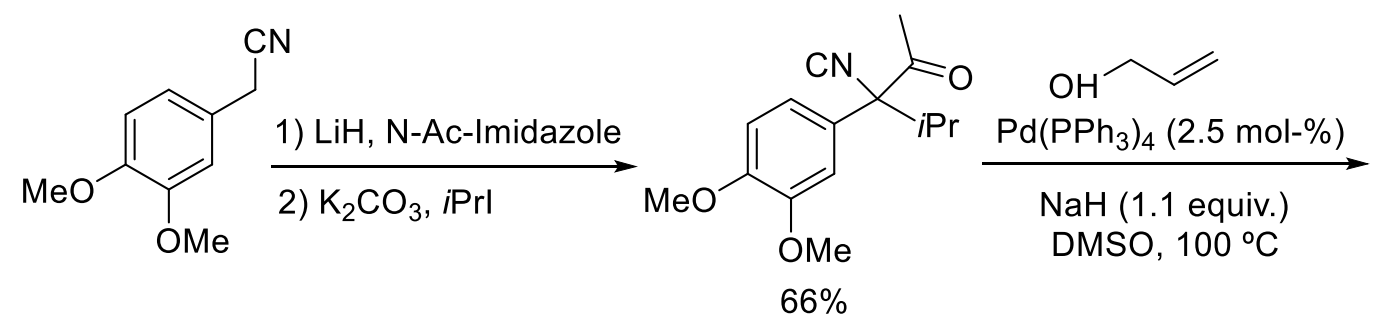<smiles>C=CCC(C)(C(C)C)C(C)(CCCN(C)CCc1ccc(OC)c(OC)c1)c1ccc(OC)c(OC)c1</smiles>

Scheme 6. Pd-catalyzed deacylative allylation of $\alpha$-arylcyanoacetones.

When isopropyl $\alpha$-arylcyanoacetates were used as substrates a very fast DaA took place at r.t. in DMSO in only 30 min (Scheme 7). ${ }^{[5]}$ However, $\alpha$-cyano ethyl esters required an excess of the allyl alkoxide due to the formation of sodium ethoxide and consequently diethyl carbonate. Therefore, a higher concentration of allyl alcohol was necessary to compete with the ethoxide in the retro-Claisen process. Since secondary alkoxides are ineffective in this retro-Claisen condensation, isopropyl cyanoacetates can be efficiently used in this DaA. An alternative synthesis of the verapamil precursor, starting from isopropyl cyanoacetate, was more efficient than the previous one affording the corresponding product in $91 \%$ overall yield (Scheme 7).

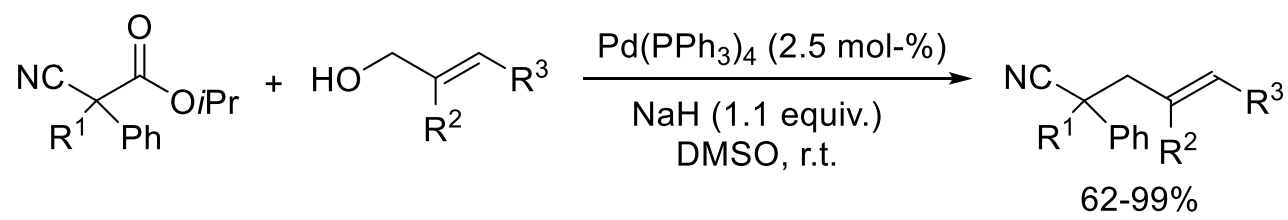

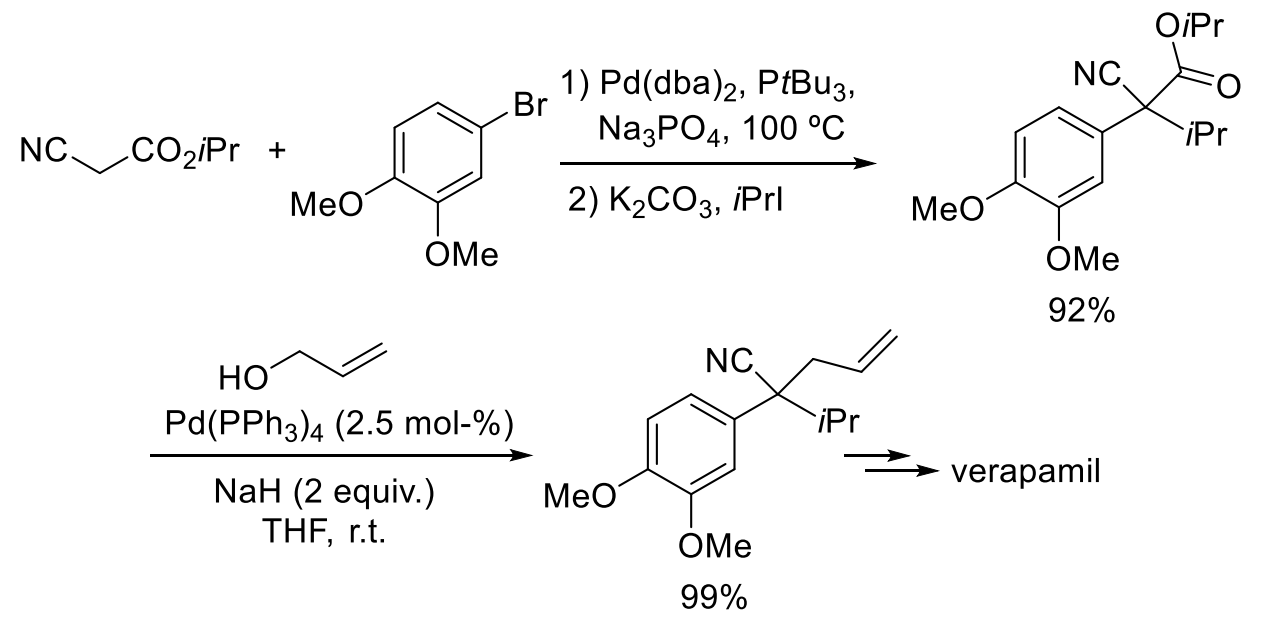

Scheme 7. Pd-catalyzed deacylative allylation of isopropyl $\alpha$-arylcyanoacetates.

The same authors studied the tandem bisallylation ${ }^{[5]}$ of $\alpha$-phenyl substituted acetylacetones, $\alpha$-cyanoacetones and $\alpha$ cyanoacetates such as it was previously described for $\alpha$-nitroacetone derivatives ${ }^{[4]}$ already showed in Scheme 3 (eq. 2). In these reactions, cinnamyl acetate was used for the first allylation and different allylic alcohols for the DaA providing, in an 
one-pot procedure, the corresponding 1,6-heptadienes (Scheme 8). The group concluded that the DaA by allylic alkoxides (pKa 30) can generate nitronates (pKa 17), enolates (pKa 18-25) and nitriles (pKa 23) stabilized anions.<smiles>[CH2+]C(C(=O)OC/C=C/c1ccccc1)C(Br)C(C)=O</smiles><smiles>[CH+]C([CH2+])C([Al])C#N</smiles>

$\mathrm{NaH}(2.1$ equiv.)<smiles>[R]/C=C(\[R])CO[N+](=O)[O-]</smiles><smiles>[R]C=C([R])CC(Br)(C/C=C/P)C(C)=O</smiles><smiles>[R]/C=C(\[R])CC([Al])([Al])C/C=C/P</smiles><smiles>N#CC(C(=O)O[PH+][Co]OCC=Cc1ccccc1)c1ccccc1</smiles><smiles>C=CCC(C#N)(C/C=C/c1ccccc1)c1ccccc1</smiles>

Scheme 8. Bisallylation of acetylacetones, cyanoacetones, and isopropyl $\alpha$-phenylcyanoacetate.

Asymmetric deacylative allylation of cyclic ketone enolates with allylic alcohols has been described by Tunge et al. ${ }^{[6]}$ Racemic studies with tetralones, substituted at the $\alpha$-position by an acetyl group,demonstrated to be better substrates than propanoyl or formyl derivatives for the DaA with different allylic alcohols working with NaH in THF at r.t. (Scheme 9). This DaA has been carried out with different tetralones substituted by electron-withdrawing and -donating groups being scaled up to $>6 \mathrm{~g}$. These reaction conditions were appropriate for other tetralone cores such as indanone and benzosubarone.<smiles>[R2]c1cccc2c1CCC([R])(C(C)=O)C2=O</smiles>

Scheme 9. Pd-catalyzed deacylative allylation of tetralones.<smiles>[R][R]1cccc2c1CCC([R])(CC([R])=C)C2=O</smiles>

$55-93 \%$

For the asymmetric version of this DaA, different chiral PHOX ligands were assayed. ${ }^{[6]}$ Ligands L1 and L2 gave the best enantioselectivities affording highly enantioenriched $\alpha, \alpha$-diallylated tetralones (Scheme 10). This methodology has been applied to the synthesis of the Clive-Stoltz intermediate ${ }^{[7]}$ of the antiviral (+)-hamigeran $\mathrm{B} \cdot{ }^{[8]}$ In this case, the DaA took place in higher yield and ee than by DcA performed by Stoltz et al. ${ }^{[7]}$ 


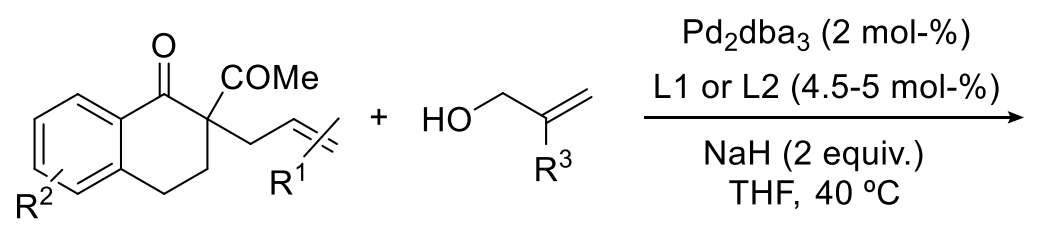<smiles>[R][R]C=CC[C@]1(CC([R])=C)CCc2ccccc2C1=O</smiles>

L1: $72-89 \%, 72-89 \%$ ee L2: $65-88 \%, 77-95 \%$ ee<smiles>COc1cc(C)cc2c1CCC(C)(C(C)=O)C2=O</smiles><smiles>C=CC[C@]1(C)CCc2c(OC)cc(C)cc2C1=O</smiles><smiles>CC(C)(C)[C@H]1COC(c2ccccc2P)=N1</smiles><smiles>CCCCC(C)(C)C</smiles>

L1

L2: $\mathrm{Ar}=4-\mathrm{CF}_{3} \mathrm{C}_{6} \mathrm{H}_{4}$<smiles>[Y][Y]([Y]([H])=C)[C@H]1CC[C@]2(C)C(=O)C(=O)c3c(cc(C)c(Br)c3OC)[C@@H]12</smiles>

(+)-hamigeran B

Scheme 10. Asymmetric Pd-catalyzed deacylative allylation of tetralones.

The 2-oxindole unit is present in many natural products and biologically active molecules, specially 3,3-disubstituded 2oxindoles. ${ }^{[9]}$ Bisai et al. have reported the Pd-catalyzed deacylative allylation of $N$-alkyl-2-oxindoles bearing a methoxycarbonyl group at the 3-position with primary allylic alcohols (Scheme 11, eq. 1). ${ }^{[10]}$ The reaction took place with 5 mol-\% of $\mathrm{Pd}\left(\mathrm{PPh}_{3}\right)_{4}, \mathrm{NaH}$ as base, in toluene at r.t. in moderate to high yields. This strategy allowed the synthesis of a wide range of 2-oxindoles bearing a quaternary stereocenter at the 3-position. Secondary alcohols, such as 1-phenylallyl alcohol furnished the same product that the reaction performed with cinnamyl alcohol. Competitive experiments demonstrated that these alkylation reactions took place through an intermolecular process. The same transformation has been studied with $N$ methyl-3-acetyl-2-oxindoles and allyl or methallyl alcohol. Sequential gem-bisallylation at the 3-position has been achieved starting from the $N$-carbamoyl enol acetate with 2.5 equiv. of allylic alcohols giving 3,3-diallylated 2-oxindoles (Scheme 11, eq. 2). A tandem process starting from $N$-carbamoyl-2-oxindole (pKa 18-19) or from $N$-methyl-3-methoxycarbonyl-2oxindole (pKa 16-17), in the presence of both allyl acetate and allyl alcohol, allowed firstly the Tsuji-Trost allylation and then the DaA giving the corresponding 3,3-diallylated derivatives in $67 \%$ or $62 \%$ yield, respectively (Scheme 11 , eq. 3 and 4). 
<smiles>[R]N1C(=O)C([R])(C(C)=O)c2ccccc21</smiles><smiles>[R]C([R])=C([R])CO</smiles>
$\left[\mathrm{R}^{1}=\mathrm{Me}, \mathrm{PMB}\right.$, allyl $\mathrm{R}^{2}=$ alkyl, aryl

$$
\underset{\mathrm{NaH}(1.2 \text { equiv. })}{\stackrel{\mathrm{Pd}\left(\mathrm{PPh}_{3}\right)_{4}(5 \mathrm{~mol}-\%)}{\longrightarrow}}
$$
PhMe, r.t.

$$
\underset{\mathrm{Pd}\left(\mathrm{PPh}_{3}\right)_{4}(5 \text { mol- } \%)}{\stackrel{\mathrm{NaH}(1.2 \text { equiv. })}{\longrightarrow}}
$$
PhMe, r.t.<smiles>[R]C([R])=C([R])CC1([R])C(=O)N([R])c2ccccc21</smiles><smiles></smiles><smiles>[R]C=CCC1(C/C=C/[R])C(=O)Nc2ccccc21</smiles><smiles>C=CCC1(CC=C)C(=O)Nc2ccccc21</smiles><smiles>COC(=O)C1C(=O)N(C)c2ccccc21</smiles><smiles>C=CCOc1ccccc1</smiles><smiles>C=CCC1(CC=C)C(=O)N(C)c2ccccc21</smiles>

Scheme 11. Pd-catalyzed deacylative mono- and bis-allylation of 2-oxindoles.

The former methodology has been applied to the synthesis of dimeric cyclotryptamine alkaloids ${ }^{[1]}$ such as mesofolicanthine and meso-chimonanthine. Dimeric 2-oxindole underwent DaA with allyl alcohol in toluene at $80{ }^{\circ} \mathrm{C}$ forming the corresponding diallylated meso-bisoxindoles in good yields (Scheme 12). ${ }^{[10]}$ The $N$-methylated derivative is a useful intermediate for the total synthesis of racemic folicanthine ${ }^{[12]}$ and the $\mathrm{N}$-benzylated dimeric compound was transformed into meso-chimonanthine, which is a precursor of meso-calycanthine. ${ }^{[13]}$ 
<smiles>[R]N1C(=O)C(C)(C(OC)(OC)c2ccccc2)C(=O)N1[R]</smiles><smiles>[R]N1C(=O)C(CC=C)([C@@]2(CC=C)C(=O)N([R])c3ccccc32)c2ccccc21</smiles>

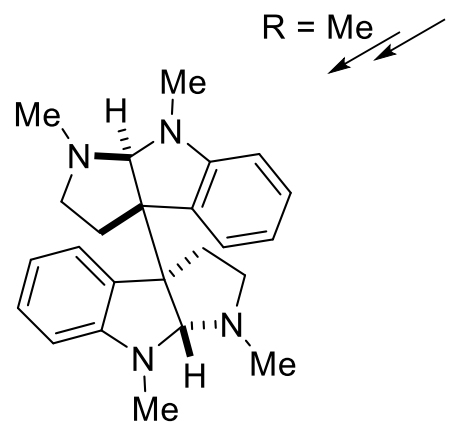

meso-folicanthine

$72-90 \%, 2.1: 1-3.1-1 \mathrm{dr}$

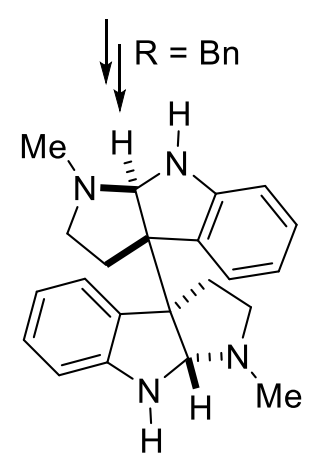

meso-chimonanthine

Scheme 12. Pd-catalyzed deacylative allylation of dimeric 2-oxindoles.

The DaA of 1,3-dimethyl-3-acetyl-2-oxindoles with allylic alcohols has been studied also by our group. ${ }^{[14]}$ This process took place with 3 mol-\% of $\mathrm{Pd}(\mathrm{OAc})_{2}$ and 1,3-bis(diphenylphosphino)propane (dppp) using LiOt $\mathrm{Bu}$ as base at r.t. in THF (Scheme 13). Primary and secondary allylic alcohols gave the corresponding 3,3-disubstituted 2-oxindoles in good yields, this process being applied to the synthesis of the precursors of esermethole ${ }^{[15]}$ and horsfiline ${ }^{[16]}$ as well as to the access to the acetylcholinesterase inhibitors physostigmine and phenserine. ${ }^{[17]}$

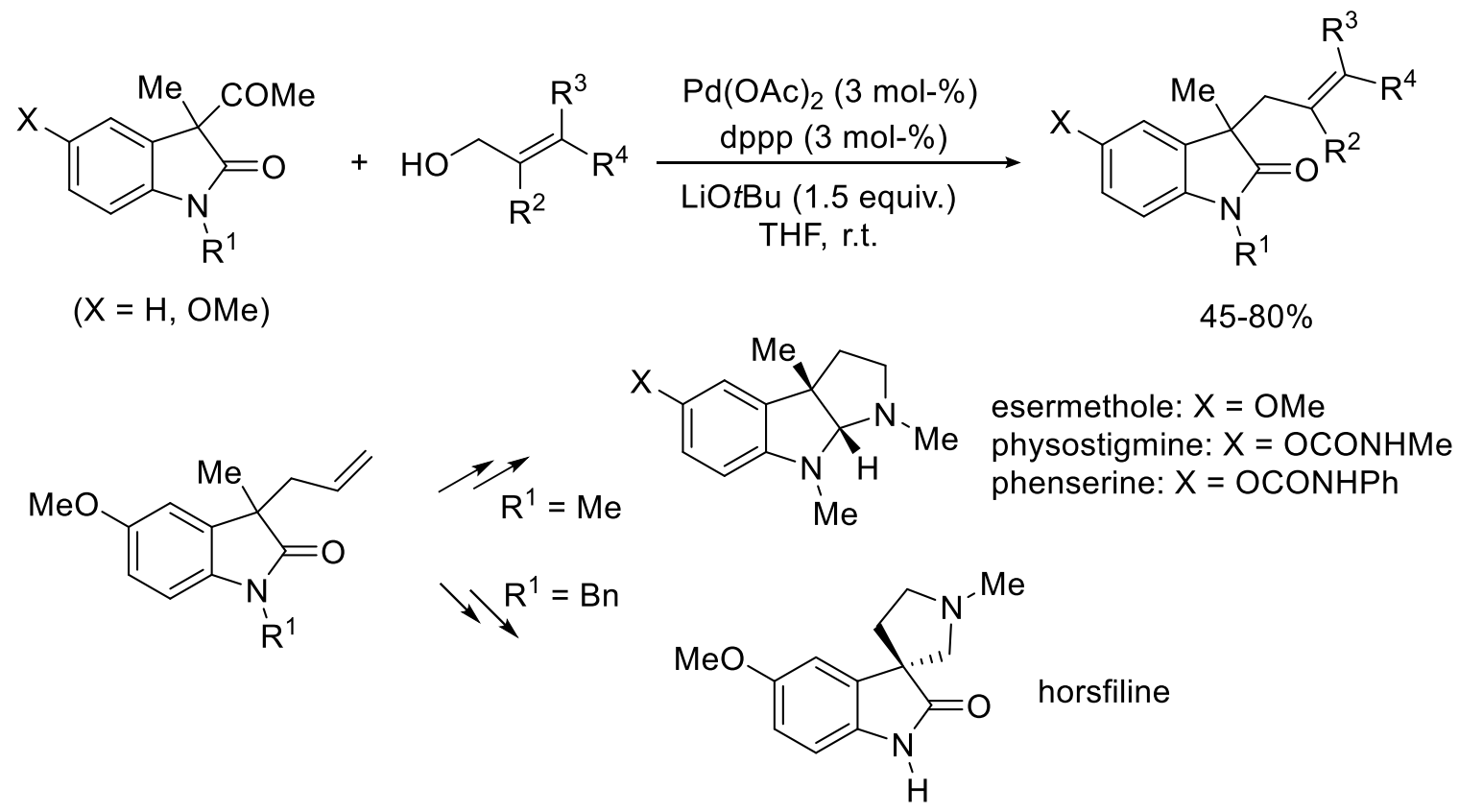

Scheme 13. Pd-catalyzed deacylativeallylation of 3-acetyl-2-oxindoles.

For the bisallylation reaction a two sequential procedure was reported. The first step, involving the monoallylation of $N$ methyl-3-acetyl-2-oxindole, was carried out under $\mathrm{Pd}(\mathrm{dba})_{2}$ and $\mathrm{rac}$-BINAP catalysis. In order to avoid the retro-Claisen reaction acid conditions were ensured by the employmentof the phosphoric acid derived from racemic BINOL as cocatalyst. The second step was performed with a different allylic alcohol using the same DaA reaction conditions affording the corresponding diallylated oxindole in $72 \%$ overall yield (Scheme 14). ${ }^{[14]}$ 


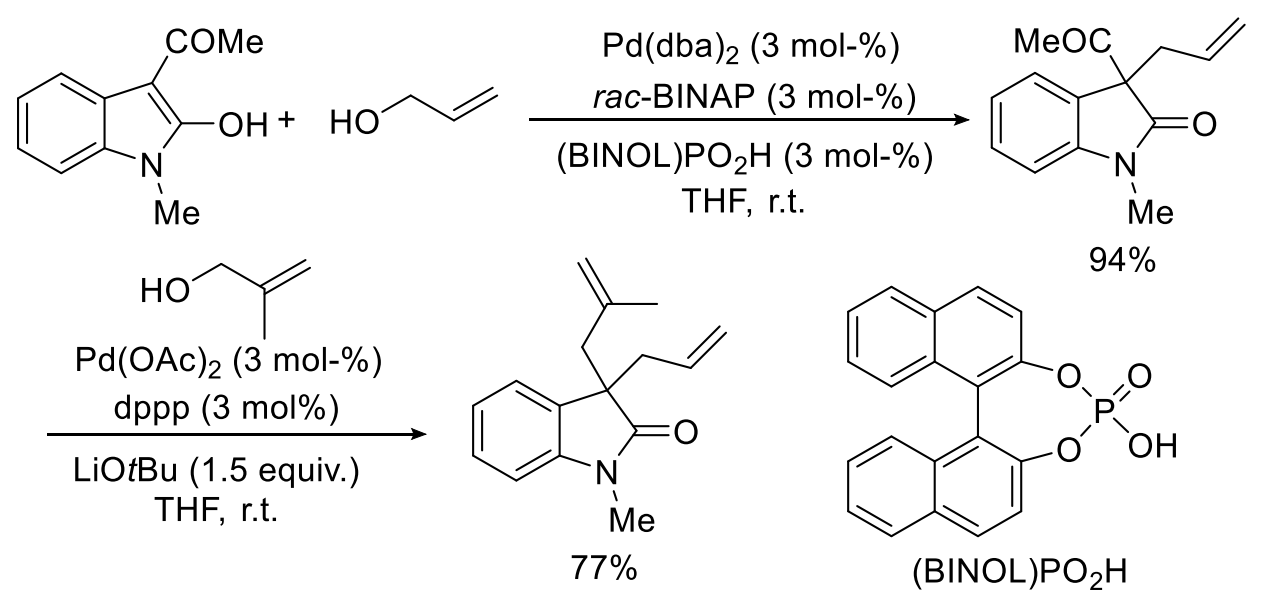

Scheme 14. Pd-catalyzed bisallylation of $N$-methyl-3-acetyl-2-oxindole.

In recent years, $\mathrm{Pd}$-catalyzed allylic $\mathrm{C}-\mathrm{H}$ alkylation has been developed as a new strategy, which avoids the use of allylic derivatives. ${ }^{[18]}$ Recently, a Pd-catalyzed deacylative $\mathrm{C}-\mathrm{H}$ allylation has been reported by Wang et al. ${ }^{[19]}$ for the creation of quaternary carbon centers. In this type of allylations the $\pi$-allylpalladium intermediate is formed from an alkene using $\operatorname{Pd}(0)$ and 2,5-di-tert-butylbenzoquinone (2,5-DTBQ) as oxidant under basic conditions. When this procedure was implemented in the reactions between $\alpha$-nitroalkyl methyl ketones and allylbenzenes,in the presence of 2 equiv. of tert-butanol and 1 equiv. of $\mathrm{H}_{2} \mathrm{O}$ at $80^{\circ} \mathrm{C}$, the corresponding allylated nitro compounds were prepared in moderate yields (Scheme 15, eq. 1). In the case of acetylacetones bearing a 4-nitrophenyl substituent the reaction occurred in higher yields affording $\alpha$-allylated ketones (Scheme 15, eq. 2). This DaA has also been carried out with ethyl $\alpha$-acetylacetates as substrates with concomitant hydrolysis of the ester group giving the corresponding $\alpha$-allylated carboxylic acids (Scheme 15, eq. 3 ).<smiles>[R]C=CCC(C)(C(C)=O)[N+](=O)[O-]</smiles><smiles>[R]C(C(C)=O)(C(C)=O)c1ccc([N+](=O)[O-])cc1</smiles><smiles>[R]C(C(C)=O)C(=O)OCC[OH2+]</smiles>

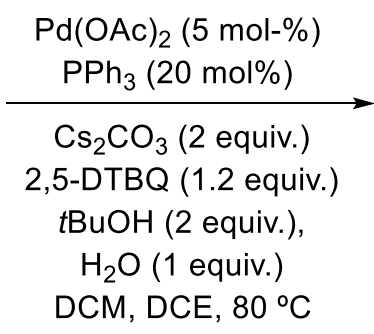<smiles>[R]C=CCC(C)(C)[N+](=O)[O-]</smiles><smiles>[14CH3][Ge]</smiles>

$25-57 \%$

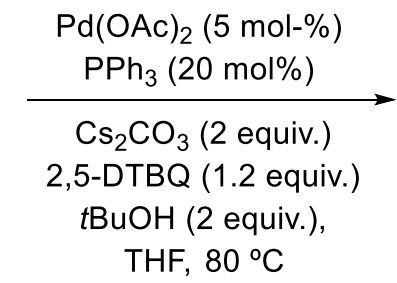

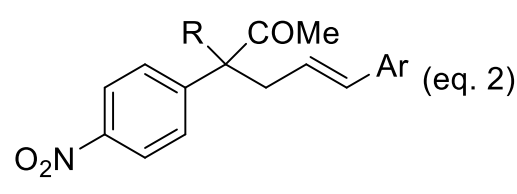

$44-92 \%$

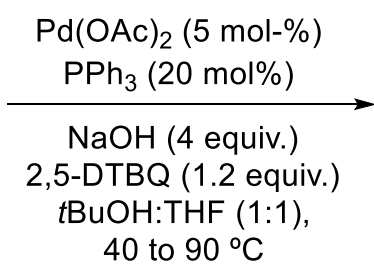

Scheme 15. Pd-catalyzed deacylative allylation with alkenes.

Deacylative benzylation of $\alpha$-cyanoesters catalyzed by $\operatorname{Pd}(0)$ has been reported by Tunge et al. ${ }^{[20]}$ Benzylic alcohols reacted with $\alpha$-aryl- $\alpha$-cyanoacetates in the presence of 5 mol- $\%$ of $\mathrm{Pd}\left(\mathrm{PPh}_{3}\right)_{4}$ using $\mathrm{NaH}$ as base in $\mathrm{THF}$ at $95^{\circ} \mathrm{C}$ providing the corresponding nitriles (Scheme 16). In this case, after retro-Claisen condensation of these substrates with the benzylic alcoholate, the corresponding benzylic carbonate was formed. This carbonate, in the presence of $\operatorname{Pd}(0)$, generates the $\eta^{3}$ - 
benzylpalladium intermediate, which has been proposed in Pd-catalyzed benzylation reactions, ${ }^{[21]}$ able to be attacked by the carbon nucleophile affording the benzylated $\beta$-arylpropanenitriles.<smiles>[X]c1ccc(C(C)(C#N)C(=O)OCC)cc1</smiles>

Scheme 16. Pd-catalyzed deacylative benzoylation of $\alpha$-cyanoesters.

Competitive experiments with benzylic and allylic alcohols demonstrated that allylation was exclusively observed. Tandem allylation-benzylation reactions of ethyl $\alpha$-phenyl- $\alpha$-cyanoacetate have been performed using allyl acetate and benzylic alcohols. First, the Tsuji-Trost allylation took place with the allyl acetate and then the DaA with the benzylic alcohol. Using the same reaction conditions for the deacylative benzylation, $\alpha$-allyl, $\alpha$-benzyl nitriles have been obtained in good yields (Scheme 17). ${ }^{[20]}$

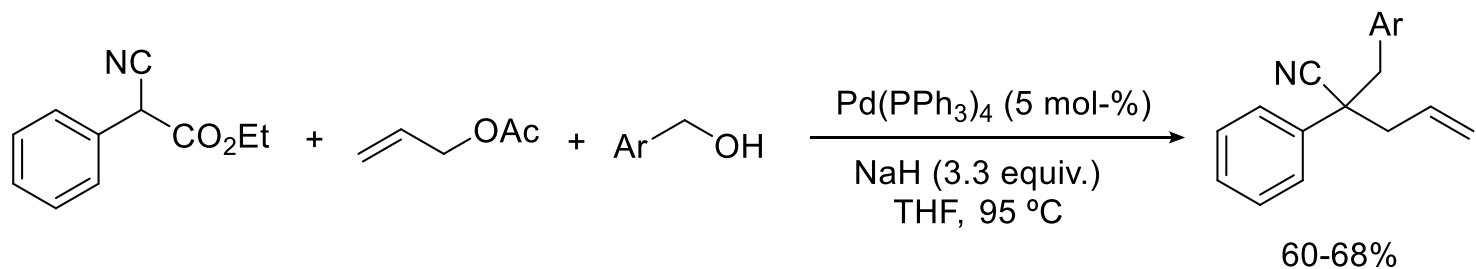

Scheme 17. Three-component allylation-deacylative benzoylation of ethyl $\alpha$-phenyl- $\alpha$-cyanoacetate.

Direct deacylative benzoylations were performed with benzylic alcohols using methyl 1,3-dimethyl-2-oxindole-3carboxylate as substrate (Scheme 18). ${ }^{[10]}$ In this case, higher temperature $\left(90^{\circ} \mathrm{C}\right)$ had to be used for completion in comparison to allylation reactions.

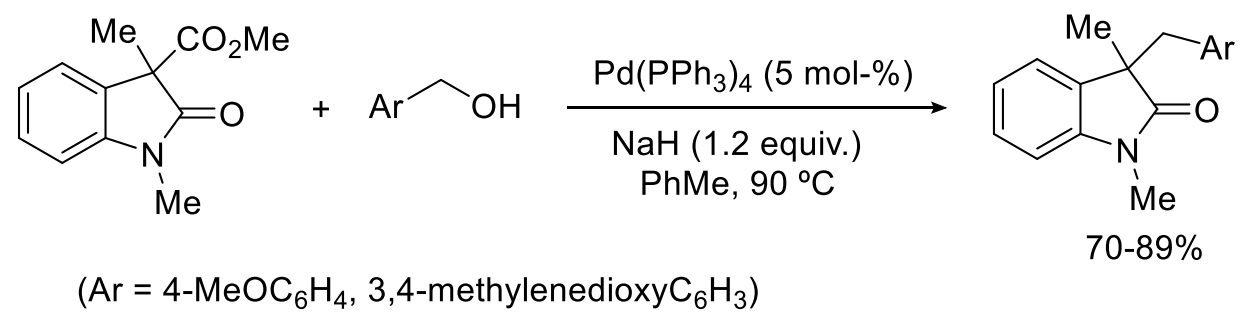

Scheme 18. Pd-catalyzed deacylative benzylation of methyl 1,3-dimethyl-2-oxindole-3-carboxylate.

Base-promoted deacylative alkylation of 3-alkyl-3-acetyl-2-oxindoles, prepared by acetylation of 2-oxindoles with acetic anhydride, ${ }^{[22]}$ has been used for the synthesis of 3,3-disubstituted oxindoles. ${ }^{[23]}$ The retro-Claisen condensation has been performed with LiOEt as base in THF at r.t. giving the corresponding carbon nucleophile, which reacted with alkyl and allyl halides as well as with ethyl chloroformate as electrophiles (Scheme 19). When electrophilic alkenes were used as electrophiles benzyltrimethylammonium hydroxide (Triton B) was the best base for achieving the corresponding conjugate addition. This methodology was applied to the synthesis of 1,3-dimethyl-3-(cyanomethyl)-2-oxindole, a precursor of esermethole, which is a precursor of the acetylcholinesterase inhibitors physostigmine and phenserine (see above and Scheme 13). ${ }^{[24]}$ 


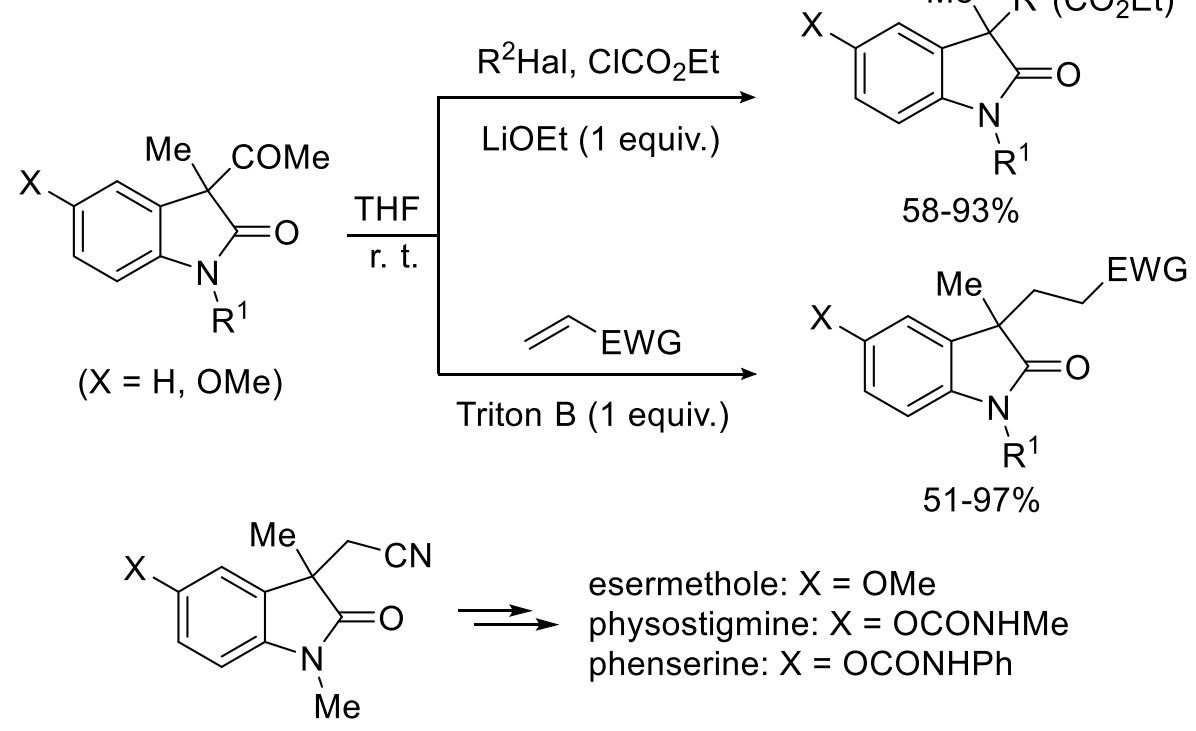

Scheme 19. Base-promoted deacylative alkylation of 3-acetyl-2-oxindoles.

Symmetrically 3,3-disubstituted 2-oxindoles have been prepared by deacylative alkylation of $N$-methyl-3-acetyl-2oxindole with alkyl and allyl halides using Triton B as base. The reaction needed to be performed using an one-pot two steps procedure giving the corresponding products in good yields (Scheme 20, eq. 1). ${ }^{[25]}$ Attempts to carry out the dialkylation in the presence of 2.5 equiv. of alkyl halide gave to the formation of monoalkylated oxindoles in a competitive manner. When 1,2-bis(bromomethyl)benzene was used as electrophile the corresponding spirocycle was obtained in $69 \%$ yield (Scheme 20 , eq. 2). On the other hand, the diallylated derivative was quantitatively transformed into the corresponding spiro compound by ring closing metathesis with the second generation Grubbs catalyst (Scheme 20, eq. 3).<smiles>CC(=O)c1c(O)n(C)c2ccccc12</smiles>

1. RHal (1 equiv.) Triton B (1 equiv.) THF, r.t.

2. $\mathrm{RHal}(1.5$ equiv.) Triton B (1.5 equiv.) THF, r.t.<smiles>[R]C1([R])C(=O)N(C)c2ccccc21</smiles>

$33-85 \%$

$\left[\begin{array}{c}\mathrm{R} \text { Hal }= \\ \text { Mel, Etl, } \mathrm{BnBr},(E)-\mathrm{PhCH}=\mathrm{CHCH}_{2} \mathrm{Br},(E)-\mathrm{EtOCOCH}=\mathrm{CHCH}_{2} \mathrm{Br}, \\ \mathrm{HCCCH}_{2} \mathrm{Br}, \mathrm{NCCH}_{2} \mathrm{Br}, \mathrm{MeOCOCH} \mathrm{CH}_{2} \mathrm{Br} \text {, geranyl bromide }\end{array}\right]$<smiles>CC(=O)c1c(O)n(C)c2ccccc12</smiles><smiles>CN1C(=O)C2(Cc3ccccc3C2)c2ccccc21</smiles><smiles>C=CCC1(CC=C)C(=O)N(C)c2ccccc21</smiles>

\section{$2^{\circ} \mathrm{G}$ Grubbs} (1 $\mathrm{mol} \%$ )

DCM, reflux<smiles>CN1C(=O)C2(CC=CC2)c2ccccc21</smiles>

$99 \%$

Scheme 20. Base-promoted deacylative dialkylation of $N$-methyl-3-acetyl-2-oxindole. 


\section{Detrifluoroacylative Alkylation}

The generation of fluoroenolates by tandem Claisen condensation, followed by a retro-Claisen process has been studied. Trifluoroacetylation of ketones with ethyl trifluoroacetate, followed by fluorination with Selectfluor and final base-promoted detrifluoroacylative alkylation with different electrophiles was described (Scheme 21). ${ }^{[26]}$ This methodology, initially reported by Colby et al., has been applied to the synthesis of pharmaceutically valuable compounds bearing quaternary stereogenic C-F centers such as it has been previously reviewed by Han and Soloshonok et al. ${ }^{[27]}$ Acyclic and cyclic ketones, including amides such as 2-oxindoles, have been selected as substrates for the generation of difluorinated and monofluorinated enolates, respectively, using mild basic reaction conditions (generally $\mathrm{Et}_{3} \mathrm{~N} / \mathrm{LiBr}$ ). Alkyl halides, carbonyl compounds, halogens, imines and nitroalkenes have been successfully used as electrophiles.

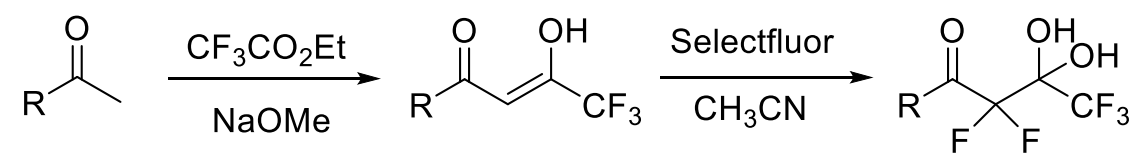

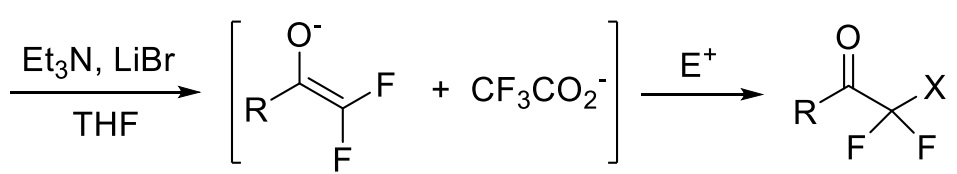

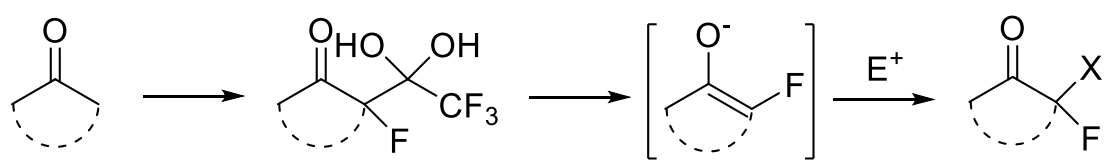

$\left[\mathrm{E}^{+}=\mathrm{RHal}, \mathrm{RCHO}, \mathrm{RR}^{\prime} \mathrm{CO}, \mathrm{Hal}_{2}, \mathrm{RCH}=\mathrm{NR}{ }^{\prime}, \mathrm{RCH}=\mathrm{CHNO}_{2}\right]$

Scheme 21. Trifluoroacetylation-fluorination-detrifluoroacylative alkylation strategy.

Concerning aldol reactions, ${ }^{[26,28]}$ a recent application of this methodology involved the reaction of cyclic fluoroenolates with $o$-phthalaldehyde using diisopropylethylamine (DIPEA) or $\mathrm{Et}_{3} \mathrm{~N}$ and $\mathrm{LiBr}$ in $\mathrm{THF}$ or $\mathrm{CH}_{3} \mathrm{CN}$ (Scheme 22). ${ }^{[29]} \mathrm{The}$ reaction proceeded through the sequence of detrifluoroacetylation, aldol addition, intramolecular cyclization giving intermediate hemiacetals, which after final oxidation with PCC, were transformed into the final lactones. The diastereoselectivity observed was moderate providing mainly the $S^{*}, R^{*}$-diastereomer using $\mathrm{Et}_{3} \mathrm{~N}$ and $\mathrm{LiBr}$ in acetonitrile at 0 ${ }^{\circ} \mathrm{C}$.<smiles>[R]c1ccc2c(c1)[X]C(F)(C(O)(O)C(F)(F)F)C(=O)C2=O</smiles>

$\left[\mathrm{X}=\mathrm{CH}_{2},\left(\mathrm{CH}_{2}\right)_{2}, \mathrm{OCH}_{2}\right]$<smiles>[R]c1cccc2c1C(=O)C(F)(C1OC(O)c3ccccc31)C2CCC</smiles>

Scheme 22. Base-promoted detrifluoroacylative aldol reaction of cyclic ketone derivatives.

The former cascade reactions were performed under enantiocatalyzed conditions with two substrates: an indanone and a tetralone derivative using $\mathrm{Et}_{3} \mathrm{~N}$ as base and the complex formed by $\mathrm{Cu}(\mathrm{OTf})_{2}$ and chiral bisoxazolines as catalysts (Scheme 23). ${ }^{[29]}$ In the case of the trifluoroacetylated indanone a $26 \%$ de was obtained and the major diastereomer was isolated in $60 \%$ 
ee using L1. The same process was applied to the tetralone derivative, giving the major product in $70 \%$ de and $86 \%$ ee using the L2 ligand.<smiles>O=C1c2ccccc2CC1(F)C(O)(O)C(F)(F)F</smiles>

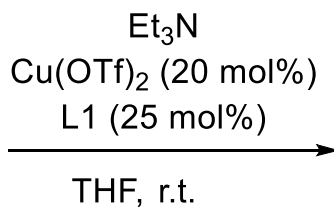

1)<smiles>O=Cc1ccccc1C=O</smiles><smiles>[X]c1ccccc1C(=O)[C@@]1(F)O[C@@H]2c3ccccc3C(=O)O[C@@H]21</smiles>

$84 \%, 26 \%$ de, $60 \%$ ee<smiles>O=C1c2ccccc2CCC1(F)C(O)(O)C(F)(F)F</smiles>

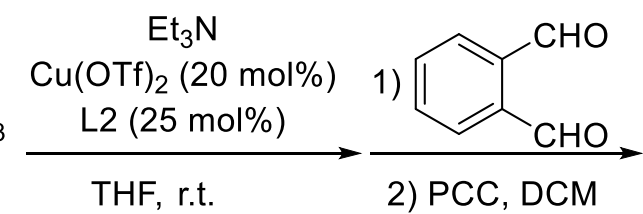<smiles>O=C1O[C@H]([C@]2(F)CCc3ccccc3C2=O)c2ccccc21</smiles>

$87 \%, 70 \%$ de, $86 \%$ ee<smiles></smiles><smiles>CC(C)(C)[C@H]1COC(CC2=N[C@@H](C(C)(C)C)CO2)=N1</smiles>

Scheme 23. Enantiocatalyzed base-promoted detrifluoroacylative aldol reaction of cyclic ketone derivatives.

Highly electrophilic $\mathrm{CF}_{3}$-containing imines have been used as electrophiles for the Mannich reaction with ketone derived fluoro-enolates. ${ }^{[30]}$ Recently, a highly diastereoselective detrifluoroacylative Mannich reaction of 3-fluoro-2-oxindole derivatives with $N$-tert-butanesulfinyl imines, derived from aliphatic, aromatic, $\alpha, \beta$-unsaturated and acetylenic aldehydes, have been reported (Scheme 24$).{ }^{[31]}$ The corresponding enantiomerically pure $\alpha$-fluoro- $\beta$-aminoindolin-2-ones were obtained using $\mathrm{Et}_{3} \mathrm{~N}$ ( 2.5 equiv.)/ $\mathrm{LiBr}$ ( 3 equiv.) in acetonitrile at $0{ }^{\circ} \mathrm{C}$ in high yields and $>96 \%$ de. The absolute configuration of these Mannich adducts differs from the obtained in the case of the $\mathrm{CF}_{3}$-containing imines. ${ }^{[29]}$ To rationalize this stereochemical outcome, a $s$-trans-configuration has been proposed for the sulfinylimines, which reacted with the fluoro-enolate by its $R e$ face through the transition state TS-A. Deprotection of the tert-butanesulfinyl group of one example, under mild acidic conditions (aqueous $\mathrm{HCl}$ in $\mathrm{MeOH}$ ) afforded the corresponding $\alpha$-fluoro- $\beta$-amino product in $89 \%$ yield and $>99 \%$ ee.

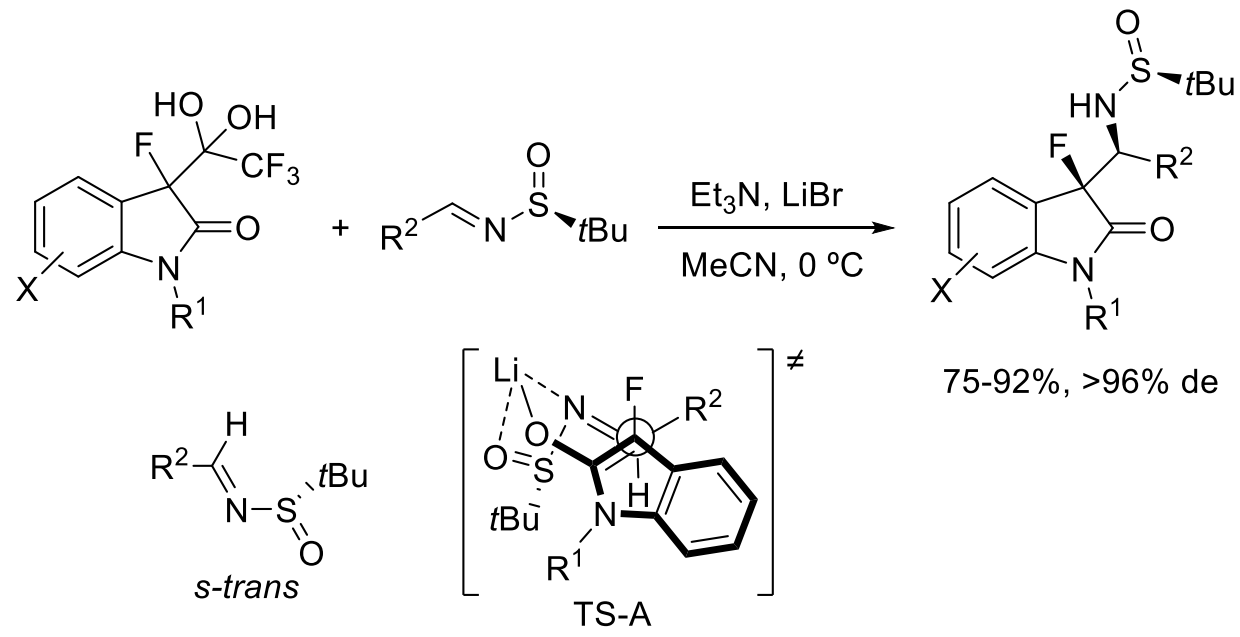

Scheme 24. Base-promoted diastereoselective detrifluoroacylative Mannich reaction of 2-oxindole derivatives.

Enantiocatalyzed detrifluoroacylative Michael addition reactions of cyclic ketone derived $\alpha$-fluoroenolates to 1,1bis(phenylsulfonyl)ethylene has been also recently achieved by Han and Soloshonok et al. ${ }^{[32]}$ In this case, the complex formed by $\mathrm{Cu}(\mathrm{OTf})_{2}$ and a chiral diamine as ligand has been used as catalyst in 10 mol-\% loading and 3 equiv. of diisopropylethylamine (DIPEA) as base in THF at $-10^{\circ} \mathrm{C}$ (Scheme 25). This procedure has been performed with indanones, tetralones, benzoheptanones, chromen-4-one and also 4-methylacetophenone affording the corresponding Michael adducts in high yields and good enantioselectivities. The stereochemical outcome has been explained by TS-B in which the Si-face of 
the enolate reacted with the Michael acceptor due to the coordination to the $\mathrm{Cu}$ atom not only by the oxygen atom of the enolate but also of the sulfone.
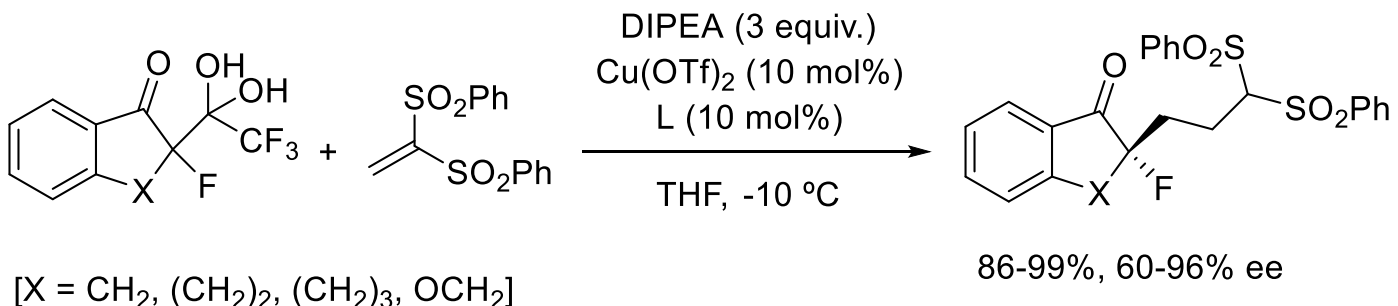

$\left[\mathrm{X}=\mathrm{CH}_{2},\left(\mathrm{CH}_{2}\right)_{2},\left(\mathrm{CH}_{2}\right)_{3}, \mathrm{OCH}_{2}\right]$

$86-99 \%, 60-96 \%$ ee<smiles>N[C@H](Nc1ccccc1)C(Nc1ccccc1)c1ccccc1</smiles>

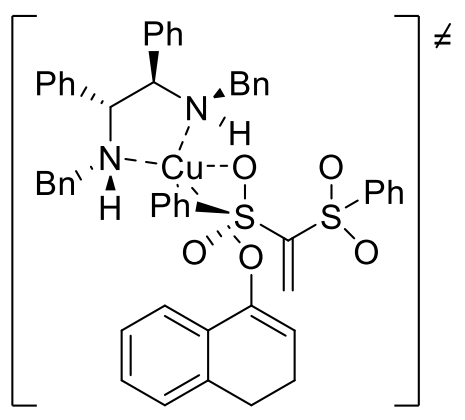

TS-B

Scheme 25. Enantiocatalyzed base-promoted detrifluoroacylative Michael addition of cyclic ketone derivatives.

Recently, a chemoselective $\mathrm{S}_{\mathrm{N}} 2$ ' detrifluoroacetilative allylation of3-fluorinated 2-oxindole derivatives has been carried out with Morita-Baylis-Hillman carbonates using 3 equiv. of $\mathrm{LiBr}$ and tetramethylguanidine (TMG) in THF at r.t. The intermediate 3-fluoro-2-oxindole enolates reacted with $\mathrm{MBH}$ derivatives steroselectively giving mainly the (E)-products (Scheme 26). ${ }^{[33]}$ In this case, TS-A has been proposed as the most probable transition state, avoiding repulsive electrostatic interactions between the functional groups.

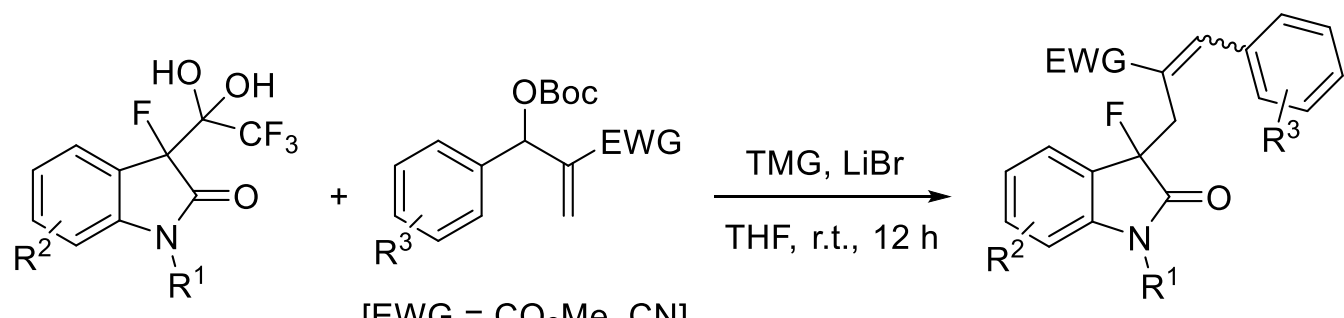

$\left[\mathrm{EWG}=\mathrm{CO}_{2} \mathrm{Me}, \mathrm{CN}\right]$

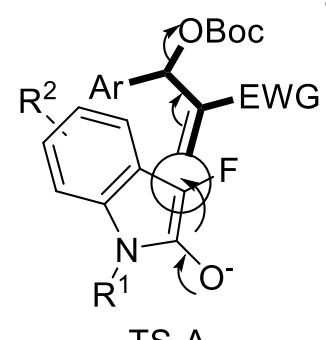

$80-95 \%, E / Z: 85 / 15-96 / 4$

\section{TS-A}

Scheme 26. Base-promoted detrifluoroacylative $S_{\mathrm{N}} 2$ ' allylation of 2-oxindole derivatives.

\section{Deacylative Oxidation}

Bisai et al. described during their studies on Pd-catalyzed deacylative allylation of methyl 2-oxindole-3-carboxylates the concomitant formation of 3-alkyl-3-hydroxy-2-oxindoles. Then, the deacylative oxidation was performed with two examples in the presence of the sodium allyl alcoholate in the presence of an oxygen balloon at $1 \mathrm{~atm}$ at r.t. givingthe corresponding 3hydroxy-2-oxindoles in good yields (Scheme 27). ${ }^{[10]}$ 
<smiles>[R]C1(C(=O)OC)C(=O)N(C)c2ccccc2C1([R])O</smiles>

Scheme 27. Deacylative oxidation of methyl 2-oxindole-3-carboxylates.

In our hands, a similar deacylative oxidation has been achieved in the case of 3-alkyl-3-acetyl-2-oxindoles using 1 equiv. of LiOEt as base in THF under air at r.t. (Scheme 28). ${ }^{[14]}$ This base promoted the deacylative oxidation giving the corresponding 3-hydroxyindoles in good yields. It has been proposed that the in situ generated enolate suffered a radical oxidation by oxygen.

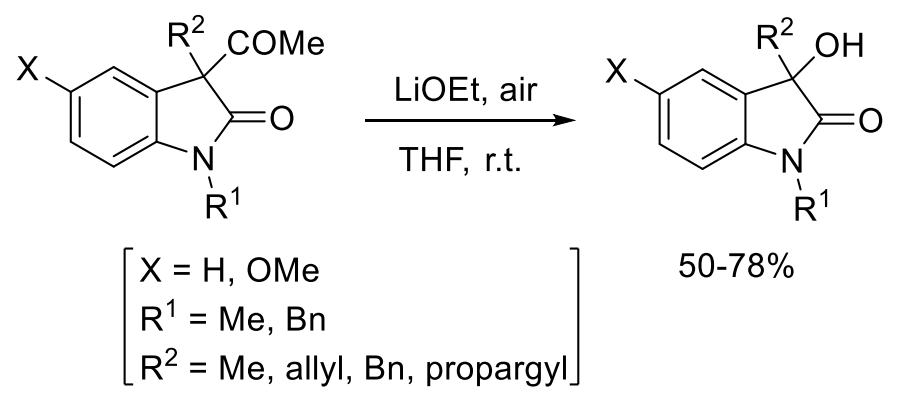

Scheme 28. Deacylative oxidation of 3-acetyl-3-alkyl-2-oxindoles.

The former methodology avoided the use of oxidants ${ }^{[34]}$ for the synthesis of 3-hydroxy-2-oxindoles. These compounds are important synthetic intermediates for the preparation of biological active alkaloids ${ }^{[35]}$ such as convolutamydines, donaxaridine, maremycin, dioxibrassinine, celogentin K, welwitindolinone C, TMC- 95's, 3'-hydroxyglucoisatisin and several others.

\section{Other Deacylative Reactions}

Palladium-deacylative cross-coupling reaction of aryl iodides with acetyldiazoacetates allowed the synthesis of aryl diazoacetates. ${ }^{[36]}$ The reaction took place using 1.5 mol-\% of $\mathrm{Pd}\left(\mathrm{PPh}_{3}\right)_{4}$ as catalyst and $\mathrm{NaOH}$ as base in ethanol at r.t. in moderate to good yields. With the aim to explain this transformation a possible mechanism has been proposed. Intermediates I or II can experiment nucleophilic attack by the hydroxide anion generating intermediate III. This intermediate III underwent deacylation forming the intermediate IV which, after reductive elimination of $\operatorname{Pd}(0)$, gave the final product (Scheme 29). In addition, a detrifluoroacylative cross-coupling of trifluoroacetyldiazoacetates with aryl iodides catalyzed by $\mathrm{Pd}\left(\mathrm{PPh}_{3}\right)_{4}$ gave the same aryldiazoacetates using $\mathrm{K}_{2} \mathrm{CO}_{3}$ as base in $\mathrm{MeOH}$ at r.t. 
<smiles></smiles>

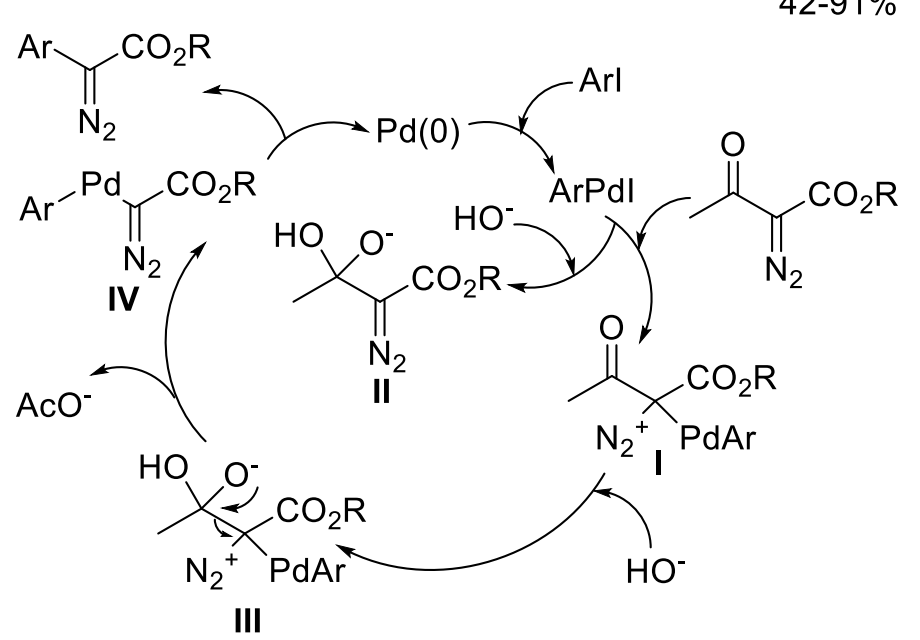

Scheme 29. Pd-catalyzed deacylative cross-coupling of acetyldiazoacetates with aryl iodides.

The deacylative Pd-catalyzed cross-coupling reaction has been applied to the reaction of acetyldiazophosphonates with aryl iodides using $\mathrm{K}_{2} \mathrm{CO}_{3}$ as base in a 1:1 mixture of toluene and methanol, the corresponding aryldiazophosphonates being obtained in good yields (Scheme 30 ). ${ }^{[35]}$

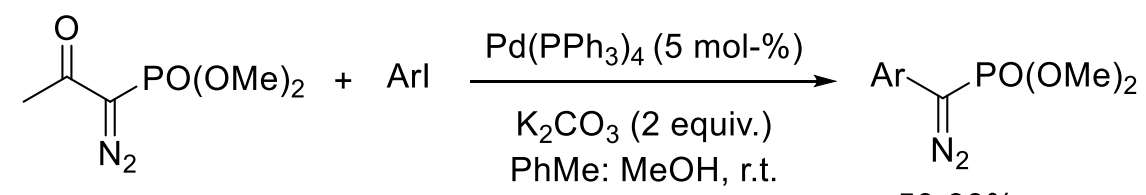

$50-93 \%$

Scheme 30. Pd-catalyzed deacylative cross-coupling of acetyldiazophosphonates with aryl iodides.

Recently, it has been reported a tandem Pd-catalyzed deacylative cross-coupling followed by denitrogenative cyclization of acetyldiazoacetates with 2-iodoazoarenes and 2-iodoaryltriazenes giving $2 \mathrm{H}$-indazoles (Scheme 31). ${ }^{[3]}$ The deacylative process took place under mild reaction conditions using 5 mol- $\%$ of $\mathrm{Pd}\left(\mathrm{PPh}_{3}\right)_{4}$ as catalyst and $\mathrm{NaOH}$ as base at r.t. The denitrogenative cyclization was promoted by heating at $70{ }^{\circ} \mathrm{C}$. These azaheterocycles are important class of compounds in drug discovery as pharmacophores. ${ }^{[38]}$<smiles>[R][R]1cccc(N=Nc2cc[R4](CC)cc2I)c1</smiles>

1) $\mathrm{Pd}\left(\mathrm{PPh}_{3}\right)_{4}(5 \mathrm{~mol}-\%)$ $\mathrm{NaOH}(3$ equiv.) $\mathrm{EtOH}$, r.t.

2) $70^{\circ} \mathrm{C}$<smiles></smiles>

$42-90 \%$<smiles>[R1]c1[R1]cc2c(C(=O)OCC)n(N3CCOCC3)nc2c1</smiles>

$53-73 \%$

Scheme 31. Pd-catalyzed deacylative cross-coupling of acetylacetates with aryl iodides followed by denitrogenative cyclization. 


\section{Conclusions}

According to the recent advances concerning deacylative reactions it can be deduced the great potential of this methodology in enolate chemistry for the generation of quaternary stereocenters, which is not a very easy goal in synthetic organic chemistry. They can be carried out under very mild reaction conditions with simple bases instead of a cryogenic deprotonation process with very strong bases. This implies a higher tolerance of functional groups ensuring elevated conversions and an excellent control of the chemoselectivity. Starting materials (1,3-dicarbonyl compounds) can be prepared by simple Claisen condensation and the strategically located acyl group is used as "traceless" directing group in a retroClaisen condensation promoted by a base. In situ tandem deacetylation followed by functionalization of the enolate simplify the synthetic procedures. Pd-catalyzed deacylative allylations with allylic alcohols allowed the retro-Claisen cleavage by the allylic alcoholate forming not only the carbon nucleophile bond but also the allylic acetate or carbonate able to generate the $\pi$-allylpalladium intermediate. Allylated nitro compounds, nitriles, ketones and 2-oxindoles can be regioselectively prepared. Several applications to the synthesis of pharmaceuticals and natural products were always envisaged. The Pd-catalyzed deacylative methodology can be also carried out with benzylic alcohols. When allylarenes are employed as electrophiles Pdcatalyzed deacylative allylation can be performed by $\mathrm{C}-\mathrm{H}$ activation. For the base-promoted deacylative reactions alkyl halides and electrophilic alkenes allow the 3,3-functionalization of 2-oxindole enolates. Detrifluoroacylative reactions have been extensively applied to the generation of fluoroenolates which reacted with alkyl halides, carbonyl compounds, imines, electrophilic alkenes and halogens giving valuable fluorinated intermediates. Base-promoted deacylative oxidation of 2oxindoles can be performed just using oxygen or air at room temperature giving the corresponding 3-hydroxy-2oxindolesspontaneously, which are important synthetic intermediates. Finally, in the case of acetyldiazoacetates or phosphonates, Pd-catalyzed deacylative cross-coupling reactions with aryl iodides allowed the synthesis of the corresponding aryldiazo compounds and $2 \mathrm{H}$-indazoles pharmacophores.

\section{Acknowledgments}

We gratefully acknowledge financial support from the Spanish Ministerio de Economía y Competitividad (MINECO) (projects CTQ201343446-P and CTQ2014-51912-REDC), the Spanish Ministerio de Economía, Industria y Competitividad, Agencia Estatal de Investigación (AEI) and Fondo Europeo de Desarrollo Regional (FEDER, EU) (projects CTQ2016-76782-P and CTQ2016-81797-REDC), the Generalitat Valenciana (PROMETEOII/2014/017) and the University of Alicante. A. O.-M. thanks MINECO for a predoctoral fellowship.

[1] M. Jukič, D. Šterk, Z. Časar, Curr. Org. Synth. 2012, 9, 488-512.

[2] a) For reviews, see: J. A. Tunge, E. O. Burger, Eur. J. Org. Chem. 2005, 1715-1726; b) J. D. Weaber, A. Recio, III, A. J. Grenning, J. A. Tunge, Chem. Rev. 2011, 111, 1846-1913; c) Z.-L. Wang, Adv. Synth. Catal. 2013, 355, 2745-2755.

[3] a) B. M. Trost, D. T. Styles, Org. Lett. 2007, 9, 2763-2766; b) S. R. Levine, M. R. Krout, B. M. Stolz, Org. Lett. 2009, 11, 289-292; c) J. E. De Lorbe, M. D. Lotz, S. F. Martin, Org. Lett. 2010, 12, 1576-1578.

[4] A. J. Grenning, J. A. Tunge, Angew. Chem. Int. Ed. 2011, 50, 1688-1691; Angew. Chem. 2011, 123, 1726-1729.

[5] A. J. Grenning, J. A. Tunge, J. Am. Chem. Soc. 2011, 133, 14785-14794.

[6] A. J. Grenning, C. K. Van Allen, T. Maji, S. B. Lang, J. A. Tunge, J. Org. Chem. 2013, 78, 7281-7287.

[7] a) D. L. J. Clive, J. Wang, Angew. Chem. Int. Ed. 2003, 42, 3406-3409; Angew. Chem. 2013, 115, 3528-3531.

b) H. Mukherjee, N. T. McDougal, S. C. Virgil, B. M. Stoltz, Org. Lett. 2011, 13, 825-827.

[8] K. D. Wellington, R. C. Cambie, P. S. Rutledge, P. R. Bergquist, J. Nat. Prod. 2000, 63, 79-85.

[9] For recent reviews, see: a) Z.-Y. Cao, Y.-H. Wang, Y.-P. Zeng, J. Zhou, Tetrahedron Lett.2014, 55, 2571-2584; b) G. S. Singh, Z. Y. Desta, Chem. Rev. 2012, 112, 6104-6155; c) R. Dalpozzo, G. Bartoli, G. Bencivenni, Chem. Soc. Rev. 2012, 41, 7247-7290; d) K. Shen, X. Liu, X. Feng, Chem. Sci. 2012, 3, 327-334; e) F. Zhou, Y.-L. Liu, J. Zhou, Adv. Synth. Catal. 2010, 352, 1381-1407; f) C. V. Galliford, K. A. Scheidt, Angew. Chem. Int. Ed. 2007, 46, 8748-8758; Angew. Chem. 2007, 119, 8902-8912.

[10] N. Kumar, M. K. Das, S. Ghosh, A. Bisai, Chem. Commun. 2017, 53, 2170-2173.

[11] These alkaloids are found in plants and animals and have a wide array of biological properties. For a review, see: P. Ruiz-Sanchis, S. A. Savina, F. Albericio, M. Álvarez, Chem. Eur. J. 2011, 17, 1388-1408. 
[12] a) S. Ghosh, S. Chaudhuri, A. Bisai, Org. Lett. 2015, 17, 1373-1376; b) S. Ghosh, S. Chaudhuri, A. Bisai, Chem. Eur. J. 2015, 21, 17479-17484.

[13] a) J. T. Link,L. E. Overman, J. Am. Chem. Soc.1996, 118, 8166-8167; b) C. Menozzi, P. I. Dalko, J. Cossy, Chem. Commun. 2006, 4638-4640.

[14] A. Ortega-Martínez, R. de Lorenzo, J. M. Sansano, C. Nájera, Tetrahedron 2017, 74, 253-259.

[15] B. M. Trost, Y. Zhang, J. Am. Chem. Soc. 2006, 128, 4590-4591.

[16] B. M. Trost, M. K. Brennan, Org. Lett. 2006, 8, 2027-2030.

[17] A. Huang, J. J. Kodanko, L. E. Overman, J. Am. Chem. Soc. 2004,126, 14043-14053.

[18] For reviews, see: a) T. Jensen, P. Fristrup, Chem. Eur. J. 2009, 15, 9632-9636; b) C. S. Yeung, V. M. Dong, Chem. Rev. 2011, 111, 1215-1292; c) C. Liu, H. Zhang, W. Shi, A. Lei, Chem. Rev. 2011, 111, 1780-1824; d) F. Liron, J. Oble, M. M. Lorion, G. Poli, Eur. J. Org. Chem. 2014, 5863-5883; e) C. Zhang, S. I. You, RSC Adv. 2014, 4, 6173-6214.

[19] X.-L. Zhou, L. Ren, P.-S. Wang, J. Org. Chem. 2017, 82, 9794-9800.

[20] T. Maji, K. Ramakumar, J. A. Tunge, Chem. Commun. 2014, 50, 14045-14048.

[21] a) R. Kuwano, Y. Konda, Y. Matsuyama, J. Am. Chem. Soc. 2003, 125, 12104-12105; b) R. Kuwano, Synthesis 2009, 1049-1061; c) B. M. Trost, L. C. Czabaniuk, J. Am. Chem. Soc. 2010, 132,15534-15536; d) B. M. Trost, L. C. Czabaniuk, J. Am. Chem. Soc. 2012, 134, 5778-5781.

[22] M. Jha, T.-Y. Chou, B. Blunt, Tetrahedron 2011, 67, 982-989.

[23] A. Ortega-Martínez, C. Molina, C. Moreno-Cabrerizo, J. M. Sansano, C. Nájera, Synthesis 2017, 49, 5203-5210.

[24] A. Pinto, J. Jia, L. Neuville, J. Zhu, Chem. Eur. J. 2007, 13, 961-967.

[25] A. Ortega-Martínez, C. Molina, C. Moreno-Cabrerizo, J. M. Sansano, C. Nájera, An. Acad. Bras. Cienc. 2018, 90, in press.

[26] a) C. Han, E. H. Kim, D. A. Colby, J. Am. Chem. Soc. 2011, 133, 5802-5805; b) I. Saidalimu, X. Fang, X.-P. He, J. Liang, X. Yang, F. Wu, Angew. Chem. Int. Ed. 2013, 52, 5566-5570; Angew. Chem. 2013, 125, 5676-5680; c) P. Zhang, C. Wolf, Angew. Chem. Int. Ed. 2013, 52, 7869-7873; Angew. Chem. 2013, 125, 8023-8027.

[27] a) H. Mei, C. Xie, J. L. Aceña, V. A. Soloshonok, G.-V. Röschenthaler, J. Han, Eur. J. Org. Chem. 2015, 6401-6412; b) L. Zhang, W. Zhang, W. Sha, H. Mei, J. Han, V. A. Soloshonok, J. Fluorine Chem. 2017, 198, 2-9.

[28] a) C. Xie, L. Wu, J. Han, V. A. Soloshonok, Y. Pan, Angew. Chem. Int. Ed. 2015, 54, 6019-6023; b) W. Sha, L. Zhang, X. Wu, H. Mei, V. A. Soloshonok, Y. Pan, J. Han, J. Fluorine Chem. 2016, 184, 28-35; c) W. Sha, L. Zhang, W. Zhang,H. Mei, V. A. Soloshonok, J. Han, Y. Pan, Org. Biomol. Chem. 2016, 14, 7295-7303.

[29] W. Sha, L. Zhang, X. Wu, H. Mei, J. Han, V. A. Soloshonok, Y. Pan, J. Fluorine Chem. 2017, 196, 14-23.

[30] a) C. Xie, L. Wu, H. Mei, V. A. Soloshonok, J. Han, Y. Pan, Org. Biomol. Chem. 2014, 12, 7836-7843; b) C. Xie, L. Wu, H. Mei, V. A. Soloshonok, J. Han, Y. Pan, Tetrahedron Lett. 2014, 55, 5908-5910; c) C. Xie, L. Wu, J. Zhou, H. Mei, V. A. Soloshonok, J. Han, Y. Pan, J. Fluorine Chem. 2015, 172, 13-21; d) C. Xie, Y. Dai, H. Mei, J. Han, V. A. Soloshonok, Y. Pan, Chem. Commun. 2015, 51, 9149-9152; e) C. Xie, L. Zhang, W. Sha, V. A. Soloshonok, J. Han, Y. Pan, Org. Lett. 2016, 18, 3270-3273.

[31] C. Xie, W. Sha, Y. Zhu, J. Han, V. A. Soloshonok, Y. Pan, RSC Adv. 2017, 7, 5679-5683.

[32] Y. Zhu, W. Zhang, H. Mei, J. Han, V. A. Soloshonok, Y. Pan, Chem. Eur. J. 2017, 23, 11221-11225.

[33] Y. Zhu, H. Mei, J. Han, V. A. Soloshonok, J. Zhou, Y. Pan, J. Org. Chem. 2017, 82, 13663-13670.

[34] K. Ohmatsu, Y. Ando, T. Oi, Synlett 2017, 28, 1291-1294.

[35] For reviews, see: a) F. Zhou, Y.-L. Liu, J. Zhou, Adv. Synth. Catal. 2010, 352, 1381-1407; b) S. Hibino, T. Choshi, Nat. Prod. Rep. 2001, 18, 66-87.

[36] F. Ye, C. Wang, Y. Zhang, J. Wang, Angew. Chem. Int. Ed. 2014, 53, 11625-11628; Angew. Chem. 2014, 126, 11809-11812.

[37] W.-S. Yong, S. Park, H. Yun, P. H. Lee, Adv. Synth. Catal. 2016, 358, 1958-1967. 
[38] a) Atta-ur-Rahman, S. Malik, H. Cun-heung, J. Clardy, Tetrahedron Lett. 1985, 26, 2759-2762; b) M. De Luna, V. Lorusso, A. Latorre, G. Fanizza, G. Gargano, L. Caporusso, M. Guida, A. Catino, E. Crucitta, D. Sambiasi, A. Mazzu, Eur. J. Cancer 2001, 37, 364-368

\section{Layout 2:}

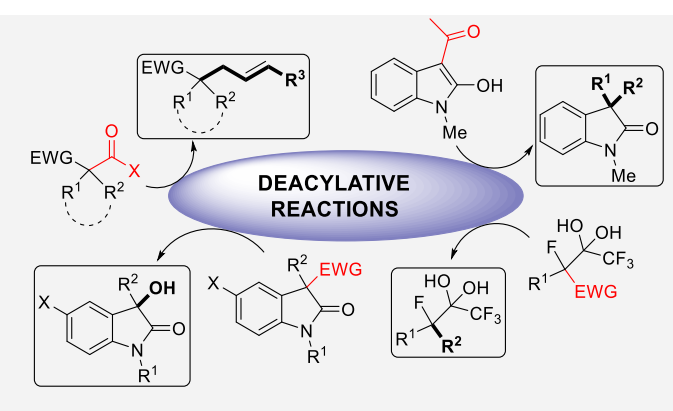

A straightforward strategy for the alkylation of enolates under mild reaction conditions under base-promoted or Pdcatalyzed reaction conditions
Enolates

Aitor Ortega-Martínez, Cynthia Molina, Cristina Moreno-Cabrerizo, José M. Sansano, Carmen

Nájera......... Page No. - Page No.

Deacylative Reactions: Synthetic Applications

Keywords: Enolates / Alkylation / Palladium catalysis / Allylic alcohols Fluorine / 


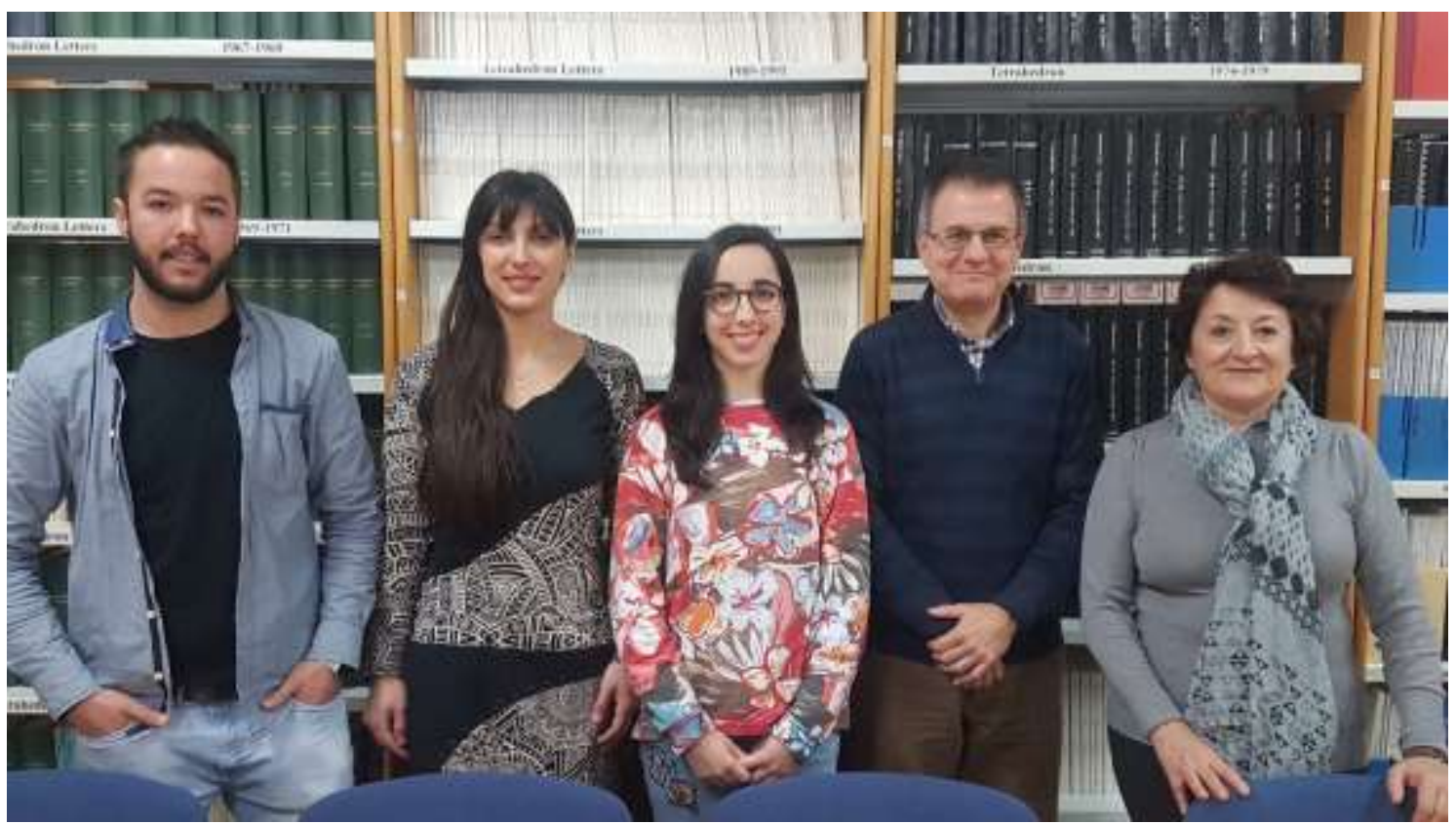

From left to right:

Aitor Ortega-Martínez was born in Benissa (Alicante) in 1990 and studied Chemistry at the University of Alicante, obtaining his B.Sc. degree in 2013. He is doing his Ph.D. studies at the same University under the supervision of Prof. Carmen Nájera and Prof. José Miguel Sansano. He is coauthor of 4 papers.

Cynthia Molina was born in Caudete (Albacete) in 1990 and studied Chemistry at the University of Alicante, obtaining her B.Sc. degree in 2015. She is doing her Ph.D. at the same University under the supervision of Prof. Carmen Nájera and Prof. José Miguel Sansano.

Cristina Moreno-Cabrerizo was born in La Nucía (Alicante) in 1990 and studied Chemistry at the University of Alicante, obtaining her B.Sc. degree in 2014. She is doing her Ph.D. at the same University under the supervision of Prof. Carmen Nájera and Prof. José Miguel Sansano.

José Miguel Sansano was born in Rojales (Alicante) in 1965, studied chemistry at the University of Alicante, where he obtained his B.Sc. and Ph.D. degrees in 1988 and 1994, respectively. His Thesis was supervised by Prof. C. Nájera and dealt about sulfone chemistry. After spending a two-year postdoctoral stay at the University of Leeds (U.K.) with Prof. R. Grigg, he joined the University of Alicante in 1996, where he was appointed Associate Professor in 2001and in 2010 to Full Professor at the same University. He is coauthor of more than 100 articles and has supervised more than 10 PhD students.

Carmen Nájera was born in Nájera (La Rioja) in 1951 and was graduated from the University of Zaragoza in 1973, obtaining her doctorate in chemistry from the University of Oviedo in 1979. She spent postdoctoral stays at the ETH (Zurich), the Dyson Perrins Laboratory (Oxford), Harvard University, and Uppsala University. She became Associate Professor in 1985 at the University of Oviedo and Full Professor in 1993 at the University of Alicante. She is coauthor of more than 400 papers and book chapters and has supervised more than $45 \mathrm{PhD}$ students. She has been awarded with the 
2006 Organic Chemistry Prize from the Spanish Royal Chemical Society of Chemistry, the 2006 Rosalind Franklin International Lectureship from the English Royal Society, the SCF 2010 French-Spanish Prize from the Sociéte Chimique de France the IUPAC 2015 Distinguished Women in Chemistry or Chemical Engineering Award and the 2018 Felix Serratosa Lectureship. In 2012 she was named full Member of the Royal Spanish Academy of Sciences, and was appointed as Active Member of the European Academy of Sciences and Arts. Professor Nájera is Manager Director of the pharma company MEDALCHEMY S.L. for the development of APIs. 